\title{
Shared Sovereignty: The Role of Expert Agencies in Environmental Law
}

\author{
Michael C. Blumm*
}

\begin{abstract}
Andrea Lang**
Environmental law usually features statutory or administrative interpretation by a single agency. Less frequent is a close look at the mechanics of implementing environmental policy across agency lines. In this Article, we offer a comparative analysis of five statutes and their approaches to sharing decision-making authority among more than one federal agency. We call this pluralistic approach to administrative decision making "shared sovereignty."

In this analysis, we compare implementation of the National Environmental Policy Act, the National Historic Preservation Act, the Endangered Species Act, the Clean Water Act, and the Federal Power Act. All of these statutes incorporate the shared sovereignty paradigm, although they vary in their interpretation of it. The first two statutes allow commenting and consulting agencies (we call both "expert" agencies) some authority, often significant, over the decisions of so-called "action agencies." More decisive authority for expert agencies exists under the Endangered Species Act. The latter two statutes give expert agencies conclusive decision-making authority.

We think that drafters of future environmental legislation and regulations may profit from this comparative analysis of pluralistic agency decision making, and we claim that the environment has benefited from the last several decades of implementing the shared sovereignty paradigm. Our view is that shared sovereignty is-and has been-an integral part of modern environmental law and should continue to be a foundational element in its future.
\end{abstract}


Introduction 610

I. The Role of Expert Comment Agencies Under NEPA......................... 612

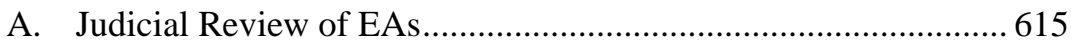

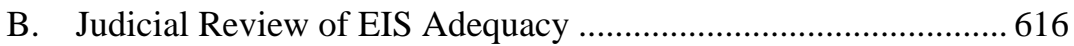

C. Project Modifications by Action Agencies .................................... 618

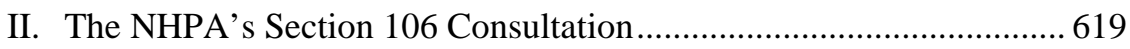

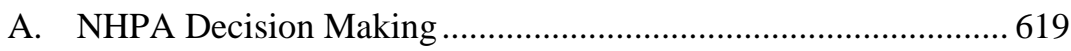

B. Consultation at the Threshold Stage: Identifying Historical

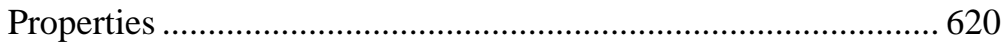

1. Tribal Involvement in Identifying Historical Properties.........621

2. Deciding Eligibility for Listing in the National Register........ 624

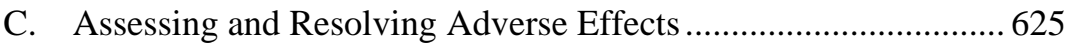

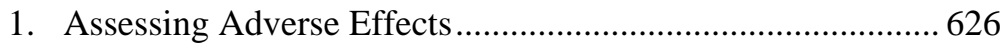

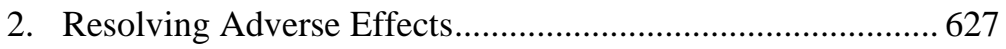

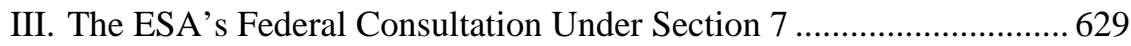

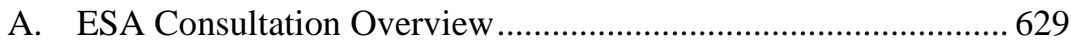

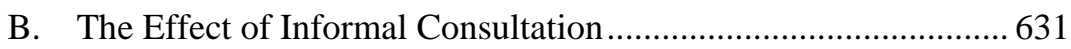

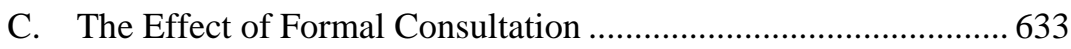

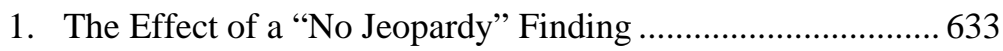

2. The Effect of a "Jeopardy" Finding ........................................634 634

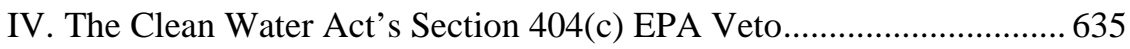

A. The Scope of the EPA's CWA Section 404 Veto Authority........ 635

B. The Effect of the EPA's Veto Power on Corps Decision Making

V. Conditions and Prescriptions Under the Federal Power Act

A. Federal Land Manager Conditioning Authority Under Section 4(e).

B. Federal Fishery Manager Conditioning Authority Under

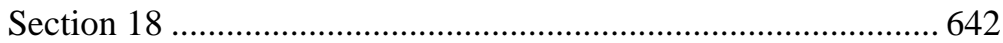

C. Recommendations to Protect Fish and Wildlife Under Section

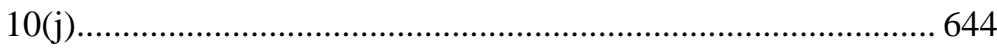

D. The Effect of the Energy Policy Act of 2005 on Conditioning

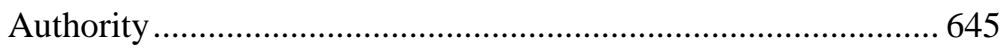

VI. Shared Sovereignty and Environmental Decision Making.................... 647

Conclusion 649

\section{INTRODUCTION}

A signature, if overlooked, contribution of environmental law to administrative law is its pathbreaking reliance on what we call "shared sovereignty" as a major decision-making paradigm. There is little question that administrative discretion lies at the center of a good deal of environmental 
law. ${ }^{1}$ Less often recognized, however, is environmental law's reliance on shared sovereignty - dividing decision-making authority among more than one agency. Since regulating activities that affect the environment is a complex endeavor which often involves difficult scientific questions and cost estimates, ${ }^{2}$ Congress has frequently chosen to divide decision making among agencies in areas such as historic preservation, endangered species, wetlands preservation, and fish, wildlife, and federal lands affected by nonfederal hydroelectric projects.

In this Article, we look at the implementation of the shared sovereignty paradigm in the context of the National Environmental Policy Act (NEPA), the National Historic Preservation Act (NHPA), the Endangered Species Act (ESA), the Clean Water Act (CWA), and the Federal Power Act (FPA). ${ }^{3}$ Our analysis begins with statutes like NEPA and the NHPA, which authorize "comment agencies" to perform only an apparently advisory role to the primary decision maker, known as the "action agency." This Article turns to "consulting agencies" in the ESA, whose opinions Justice Scalia has declared to be "virtually determinative," 4 and then we examine the conclusive decisionmaking authority accorded to "expert agencies" under the CWA and FPA.

These examples of shared sovereignty in environmental law, which foster the purposes of all five statutes we studied, make a case for Congress to continue the shared sovereignty paradigm in the future. These statutes also suggest that courts should continue to interpret this paradigm as a conscious and sustained congressional effort to curb action agencies' discretion to proceed with projects in the face of opposition from other federal agencies with statutory decision-making roles. This shared decision-making paradigm stands in contrast to the judicial deference accorded to agencies under the Chevron

Copyright (C) 2015 Regents of the University of California.

* Jeffrey Bain Faculty Scholar \& Professor of Law, Lewis and Clark Law School.

** J.D. 2015, Lewis and Clark Law School.

1. See, e.g., The Honorable David S. Tatel, The Administrative Process and the Rule of Environmental Law, 34 Harv. Envtl. L. Rev. 1 (2010).

2. See generally Joel Yellin, Science, Technology, and Administrative Government: Institutional Designs for Environmental Decisionmaking, 92 Yale L.J. 1300 (1983).

3. Although the Clean Air Act has several provisions in its prevention of significant deterioration program that, at least on their face, seem to require some interagency decision making between federal agencies or between federal land managers and states, none of these provisions produce the same kind of complex decision making that we describe as shared sovereignty. For more information on these provisions, see John-Mark Stensvaag, Preventing Significant Deterioration Under the Clean Air Act: Area Classification, Initial Allocation, and Redesignation, 41 E.L.R. 10,008, 10,016-17 (2011) (discussing the PSD program, which allows federal agencies some role in designating and redesignating clean-air areas, but most of the decisions are left to nonfederal actors). For example, the opinion of federal land managers in recommending redesignation to Class I areas (the most protective clean-air classification) is only advisory. Kerr-McGee Chem. Corp. v. U.S. Dep’t of Interior, 709 F.2d 597, 602 (9th Cir. 1983) (finding that Kerr-McGee had no standing to challenge a federal redesignation recommendation because the purely advisory opinion of the federal land manager did not result in any injury).

4. Bennett v. Spear, 520 U.S. 154, 170 (1997). 
doctrine, which demands that courts defer to agencies' reasonable interpretations of ambiguous statutory provisions. ${ }^{5}$ Instead, the paradigm reflects a policy of shared-not exclusive-decision-making authority, which courts should recognize by continuing to uphold a substantial role for "comment," "consulting," and "expert" agencies—which we often collectively refer to as expert agencies.

Part I of this Article examines the role of comment agencies in influencing decisions subject to NEPA procedures, which potentially include nearly all federal proposals. Comment agency positions have had a discernible influence on judicial scrutiny of action agencies' efforts to comply with NEPA, which courts are more likely to find inadequate when comment agencies are critical of a proposal. Part II turns to NHPA decision making, which involves quite different procedures and accords more weight to comment agencies. Part III looks to the ESA and the federal fish and wildlife agencies charged with consultation, whose biological opinions "virtually determin[e]" statutory compliance. ${ }^{6}$ Consequently, the ESA gives more decision-making authority to its consulting agencies than NEPA or the NHPA. Parts IV and V examine the operation of section 404(c) of the CWA and sections 4(e) and 18 of the FPA, provisions that provide expert agencies with determinative decision-making authority not evident in the first three statutes. Part VI suggests that the shared sovereignty approach to environmental law is an appropriate model in an administrative law world that increasingly requires multifaceted ecological, scientific, and economic expertise to make justifiable agency decisions that are in the long-run public interest.

\section{THE ROLE OF EXPERT COMMENT AGENCIES UNDER NEPA}

NEPA requires agencies proposing "major Federal actions significantly affecting the quality of the human environment" to issue an environmental impact statement (EIS). ${ }^{7}$ This seemingly straightforward requirement in fact requires two steps: (1) deciding whether a proposed action will produce any significant environmental effects, and (2) if so, preparing an EIS that sufficiently analyzes and publicly discloses those effects. ${ }^{8}$ In addition,

5. Chevron, U.S.A., Inc. v. Natural Res. Def. Council, Inc., 467 U.S. 837, 866 (1984) (“When a challenge to an agency construction of a statutory provision, fairly conceptualized, really centers on the wisdom of the agency's policy, rather than whether it is a reasonable choice within a gap left open by Congress, the challenge must fail. In such a case, federal judges—who have no constituency — have a duty to respect legitimate policy choices made by those who do.”); see E. Donald Elliott, Chevron Matters: How the Chevron Doctrine Redefined the Roles of Congress, Courts and Agencies in Environmental Law, 16 Vill. Envtl. L.J. 1 (2005).

6. Bennett, 520 U.S. at 170.

7. National Environmental Policy Act, 42 U.S.C. § 4332(2)(C) (2012); see Environmental Impact Statement, 40 C.F.R. § 1508.11 (2015) ("Environmental impact statement means a detailed written statement”).

8. 42 U.S.C. $\S 4332(2)(C)$. 
consistent with NEPA's goal of fostering informed agency decision making, ${ }^{9}$ its implementing regulations call for federal, state, local, and tribal experts to have an opportunity to comment at both stages of the process. ${ }^{10}$

Because an EIS is required only for actions that have significant environmental impacts, a threshold question is whether a proposed project's effects will be significant. ${ }^{11}$ To answer it-assuming a proposal is not categorically excluded 12 from NEPA — an agency will usually prepare a shorter Environmental Assessment (EA). ${ }^{13}$ In an EA, the action agency must analyze and explain the potential environmental impacts of its proposal and either make a "finding of no significant impact" (FONSI) or, if significant environmental effects are likely, decide to prepare an EIS. ${ }^{14}$

An EIS is a "detailed written statement" 15 that addresses, among other things, the environmental effects of the proposed action, whether any of the effects can be avoided, and reasonable alternatives to the proposal. ${ }^{16}$ Before preparing an EIS, the action agency first conducts a process called "scoping" to solicit public comment and identify the potential environmental impacts related to the proposal. ${ }^{17}$ The agency then writes a draft EIS, which is subject to comments from other agencies and the public. ${ }^{18}$ Lastly, the action agency prepares a final EIS that addresses all comments made on the draft. ${ }^{19}$

9. Purpose of NEPA, 40 C.F.R. § 1500.1(c) (2015).

10. See Whether to Prepare an Environmental Impact Statement, id. § 1501.4(b) (2015) (requiring the action agency to involve "environmental agencies, applicants, and the public, to the extent practicable, in [deciding whether a proposed action will produce any significant environmental effects]”); Inviting Comments on Draft EIS, id. § 1503.1(a)(1) (2015) (requiring the action agency to obtain comments from federal agencies with "special expertise.”); id. § 1503.1(a)(2) (requiring the action agency to request comments from tribes, states, and local agencies).

11. Significantly as Used in NEPA, id. § 1508.27 (2015) (stating agencies must consider both the "context" and "intensity" of an action to determine its significance).

12. Through notice and comment rulemaking, agencies can promulgate regulations establishing so-called "categorical exclusions" for proposals that never, individually or cumulatively, significantly affect the environment, and therefore require neither an EA nor an EIS. Categorical Exclusion in NEPA, id. $\S 1508.4$ (2015). Categorical exclusions have become a tool that action agencies have attempted to use to avoid NEPA procedure. For example, in 2005, the Forest Service attempted to categorically exclude national forest plan approvals, amendments, and revisions from NEPA. National Forest System Land Management Planning, 70 Fed. Reg. 1023 (Jan. 5, 2005). A California district court invalidated the rule in Citizens for Better Forestry v. U.S. Dep’t of Agric., 481 F. Supp. 2d 1059, $1086-87$ (N.D. Cal. 2007), but agencies have not stopped trying to similarly exclude whole kinds of projects using categorical exclusions. See generally Kevin H. Moriarty, Note, Circumventing the National Environmental Policy Act: Agency Abuse of the Categorical Exclusion, 79 N.Y.U. L. Rev. 2312 (2004); Nathaniel S.W. Lawrence, A Forest of Objections: The Effort to Drop NEPA Review for National Forest Management Act Plans, 39 E.L.R. 10,651 (2009).

13. 40 C.F.R. § 1501.4(a)-(b).

14. Environmental Assessment, id. § 1508.9(a) (2015).

15. 40 C.F.R. § $1508.11(2015)$

16. 42 U.S.C. $\S 4332(2)(C)(2012)$.

17. Scoping for NEPA, 40 C.F.R. § 1501.7 (2015).

18. Draft, Final, and Supplemental Statements, id. § 1502.9(a) (2015).

19. Id. § 1502.9(b). 
NEPA requires action agencies to consult with expert federal agencies and accept comments from federal, state, and local agencies. ${ }^{20}$ Council on Environmental Quality (CEQ) regulations ${ }^{21}$ clarify that this requirement provides a role for expert agencies at both the threshold EA and EIS stages of the NEPA process. At the EA stage, "[t]he [action] agency shall involve environmental agencies, applicants, and the public, to the extent practicable." 22 CEQ regulations also require the action agency to list the "agencies and persons consulted" in its EA. ${ }^{23}$ At the EIS stage, the regulations encourage the early involvement of expert comment agencies to comment on draft EISs ${ }^{24}$ and impose duties on both the action and commenting expert agencies. The action agency must "[o]btain" expert comments, ${ }^{25}$ and the expert agencies have a duty to provide them. ${ }^{26}$ Further, action agencies must "request" the comments of relevant state, local, and tribal interests. ${ }^{27}$

Although expert comment agencies have no direct control over NEPA action agencies, their role in the process can indirectly affect the substance of the decision. As one of us has suggested, 28 expert agency disagreement with an action agency's decision makes a reviewing court more likely to find a NEPA violation. Moreover, expert agency comments can lead to an action agency altering or abandoning proposed projects. The remainder of this Part explores three ways that expert agencies can affect NEPA decision making: (1) influencing judicial review of action agency decisions not to prepare an EIS, (2) influencing judicial review of the adequacy of an EIS, and (3) prompting action agencies to modify or abandon proposed actions.

20. 42 U.S.C. $\S 4332(2)(C)$.

21. Congress created the CEQ as an executive agency to oversee the implementation of NEPA. Id. § 4342. Its regulations implementing NEPA are found at 40 C.F.R. §§ 1501-1508 (2015).

22. 40 C.F.R. $\S 1501.4($ b) (2015).

23. Id. § 1508.9(b) (2015).

24. Id. § 1502.9(a) (requiring action agencies to produce a draft EIS and to "work with the cooperating agencies and ... obtain comments as required in part 1503.”); see id. § 1501.1 (2015) ("Emphasizing cooperative consultation among agencies before the environmental impact statement is prepared rather than submission of adversary comments on a completed document.”).

25. Inviting Comments on Draft EIS, id. § 1503.1(a)(1) (2015) (requiring the action agency to "[o]btain the comments of any Federal agency which has... special expertise with respect to any environmental impact involved or which is authorized to develop and enforce environmental standards.”).

26. Duty to Comment, id. § 1503.2 (2015) ("Federal agencies with jurisdiction by law or special expertise with respect to any environmental impact involved and agencies which are authorized to develop and enforce environmental standards shall comment on statements within their jurisdiction, expertise, or authority." (emphasis added)).

27. Id. § 1503.1(a)(2) (stating that the action agency must request comments from, inter alia, "[a]ppropriate State and local agencies which are authorized to develop and enforce environmental standards ... Indian tribes, when the effects may be on a reservation, ... and [a]ny agency which has requested that it receive statements on actions of the kind proposed.").

28. See Michael C. Blumm \& Marla Nelson, Pluralism and the Environment Revisited: The Role of Comment Agencies in NEPA Litigation, 37 Vt. L. Rev. 5 (2012); see also Michael C. Blumm \& Stephen R. Brown, Pluralism and the Environment: The Role of Comment Agencies in NEPA Litigation, 14 Harv. Envtl. L. Rev. 277 (1990). 


\section{A. Judicial Review of EAs}

Most action agencies' EAs conclude that an EIS is unnecessary, ${ }^{29}$ so the ability of expert comment agencies to affect the threshold question of whether a proposal may result in any "significant impacts" is quite important. Much of their influence exists because EA findings which disagree with their views are more vulnerable to judicial challenges.

For example, in Ocean Advocates v. U.S. Army Corps of Engineers, the Ninth Circuit overturned an Army Corps of Engineers (Corps) decision not to prepare an EIS in part because the Corps failed to adequately consider Fish and Wildlife Service (FWS) comments. ${ }^{30}$ In Ocean Advocates, BP (formerly British Petroleum) sought a permit from the Corps to extend its dock at Cherry Point in Puget Sound to increase its ability to ship crude oil. ${ }^{31}$ The FWS, concerned that the dock would result in increased tanker traffic and a corresponding increased risk of a major oil spill, submitted comments requesting that the Corps prepare an EIS addressing these effects. ${ }^{32}$ Yet the Corps issued the permit anyway on the basis of its EA's conclusion that an EIS was unnecessary. ${ }^{33}$

Ocean Advocates challenged the Corps' decision not to prepare an EIS, but the federal district court upheld the decision. ${ }^{34}$ On appeal the Ninth Circuit reversed because the Corps' analysis simply echoed BP's position on the issue 35 without properly considering the FWS's concern that the proposal would increase tanker traffic and the risk of an oil spill ${ }^{36}$ and concluded that the Corps' decision not to conduct an EIS was arbitrary and capricious. ${ }^{37}$ The case thus illustrates how expert agency comments can lead courts to find NEPA violations. 38

29. The ratio of EAs to EISs is somewhere around 100 to 1 . Wendy B. Davis, The Fox Is Guarding the Henhouse: Enhancing the Role of the EPA in FONSI Determinations Pursuant to NEPA, 39 Akron L. Rev. 35, 41 (2006). This number does not include the projects that qualify for a categorical exclusion to the EIS process or otherwise do not require an EA.

30. 402 F.3d 846, 865-66 (9th Cir. 2005).

31. Because its project would affect navigable waters, BP needed a permit from the Corps under section 10 of the Rivers and Harbors Act, 33 U.S.C. § 403 (2012); see Ocean Advocates, 402 F.3d at 855.

32. Ocean Advocates, 402 F.3d.at 855-56.

33. Id. at 856 .

34. Id. at 858 .

35. BP argued that the increased berthing capacity at the dock would actually decrease the possibility of oil spills by reducing the amount of time tankers spend waiting to dock. Id. at 857-58.

36. The concern about the risk of oil spills was also echoed by the Lummi Indian Nation and the Nooksack Indian Tribe. Id. at 855. However, in analyzing the decision not to prepare an EIS, the court focused exclusively on the Corps' failure to consider the FWS comments. Id. at 865-66.

37. Id. at 871.

38. See also Davis v. Mineta, 302 F.3d 1104, 1123 (10th Cir. 2002) (deciding that a Federal Highway Administration EA was inadequate because it failed to address EPA's concerns about the effects of a highway construction project); Sierra Club v. Van Antwerp, 661 F.3d 1147, 1156-57 (D.C. Cir. 2011) (as amended Jan. 30, 2012) (concluding that a Corps EA/FONSI for a mall development 
The volume of adverse expert agency comments may also play a role in judicial review at the EA stage. For example, in Friends of Back Bay v. U.S. Army Corps of Engineers, the Fourth Circuit ruled that the Corps had to prepare an EIS on permits to build a mooring facility and boat ramp near Back Bay National Wildlife Refuge in Virginia, ${ }^{39}$ in part because of the number of public comments opposed to the project. 40 Before issuing the permits, the Corps prepared an EA that found no significant impact. ${ }^{41}$ During public comment on the permit application, the Corps received "over 350 responses, the overwhelming majority of which were in opposition to the project." 42 The district court decided that the decision not to prepare an EIS was within the Corps' discretion, ${ }^{43}$ but the Fourth Circuit vacated that decision. ${ }^{44}$ The appeals court seemed particularly concerned that "four respected governmental entities," including the FWS, the Environmental Protection Agency (EPA), and the Virginia Department of Game and Inland Fisheries, ${ }^{45}$ opposed going forward with the project as proposed. ${ }^{46}$ As a result, the court ordered the Corps to prepare an EIS. 47

These are not isolated incidents. Previous articles contain numerous other examples of the effect of expert agency comment on judicial review. ${ }^{48}$ Taken together, these cases illustrate the effect of expert agencies' comments. Although expert agencies do not make the ultimate decision as to whether NEPA requires an EIS on a particular proposal, their comments can make it more likely that a reviewing court will conclude that an action agency erred in deciding not to prepare one.

\section{B. Judicial Review of EIS Adequacy}

Expert federal agencies, states, and tribes can also play a role when courts review the adequacy of a full EIS. The action agency's duty to obtain expert agency comments on draft EISs and to respond to comments in final EISs 49

\footnotetext{
project was inadequate because it did not properly address a FWS scientist's concern about habitat fragmentation).

39. Since the project would involve dredging and filling in navigable waters, the developer sought permits under both section 404 of the CWA, 33 U.S.C. § 1344 (2012), and section 10 of the Rivers and Harbors Act, 33 U.S.C. $§ 403$ (2012). Because many projects require both types of permits, the Corps allows the same application to serve for both and often issues them both simultaneously. See Processing of Permits, 33 C.F.R. § 325 (2015).

40. Friends of Back Bay v. U.S. Army Corps of Eng'rs, 681 F.3d 581, 590 (4th Cir. 2012).

41. Id. at 586 .

42. Id. at 583 (citations omitted).

43. Id. at 586 .

44. Id. at 589 .

45. The mayor of Virginia Beach also commented on the proposal. Id. at 583-84, 590.

46. Id. at 590 .

47. Id.

48. See Blumm \& Nelson, supra note 28; Blumm \& Brown, supra note 28.

49. Draft, Final, and Supplemental Statements, 40 C.F.R. § 1502.9(b) (2015) (stating the action agency "shall discuss at appropriate points in the final statement any responsible opposing view which
} 
includes an obligation to provide a "meaningful response to serious and considered comments by experts." 50 For example, in Western Watersheds $v$. Kraayenbrink, the Bureau of Land Management (BLM) proposed regulations that would have reduced environmental protection and public comment on federal grazing permits. ${ }^{51}$ Both the FWS and EPA raised concerns ${ }^{52}$ about the proposed regulations in their comments. ${ }^{53}$ When BLM failed to "conduct a studied review and response to concerns about the environmental implications" of its actions in its final EIS, the district court determined that the EIS violated NEPA. 54 The Ninth Circuit affirmed and enjoined enforcement of the regulations. 55

Comments by states and tribes also may affect a reviewing court's determination on the adequacy of EISs. In Western Watersheds both the district court and the Ninth Circuit found the EIS inadequate based on BLM's failure to address not only FWS's concerns, but also those of the New Mexico Department of Game and Fish, California Department of Fish and Game, Arizona Department of Game and Fish, and other expert state agencies.56 Likewise in Audubon Society v. Department of Navy, the Fourth Circuit relied on state comments to affirm a district court decision on the adequacy of the Navy's EIS on a proposed landing field for its aircraft. ${ }^{57}$ In that case, the state wildlife agency's comments on the EIS expressed concern about accidental bird strikes. 58 The district court decided, and the Fourth Circuit affirmed, that the Navy failed to adequately address the state agency's concerns in its EIS. 59

Tribal comments played a similar role in Northern Cheyenne Tribe $v$. Norton. ${ }^{60}$ There BLM prepared an EIS analyzing the effects of developing coal

was not adequately discussed in the draft statement and shall indicate the agency's response to the issues raised.”).

50. W. Watersheds Project v. Kraayenbrink, 632 F.3d 472, 492-93 (9th Cir. 2011).

51. Id. at 476 .

52. In fact, BLM's own experts raised the same concerns about the grazing permits. See id. at 487.

53. FWS was concerned that "the proposed reduction in public oversight may constrain biologists and range conservationists from recommending and implementing management changes and that '[FWS] believe[s] these aspects of the proposed revisions have the potential to be detrimental to fish and wildlife resources.'” Id. at 488 (alteration in original) (citations omitted). State agencies raised similar concerns about the proposed regulations, see id.

54. Id. at 492.

55. Id. at 492-93 ("When an agency, such as the BLM, submits proposed regulatory changes for public comment and then offers no meaningful response to serious and considered comments by experts, that agency renders the procedural requirement meaningless and the EIS an exercise in form over substance." (citations omitted)).

56. Id. at 492 ("[T] $]$ he BLM never seriously considered the concerns raised by ... the California Department of Fish and Game, among others, that the 2006 Regulations weaken the ability of the BLM to manage rangelands in a timely fashion.”).

57. 422 F.3d 174, 181 (4th Cir. 2005).

58. Id. at 189-90.

59. Id. at 191-92.

60. 503 F.3d 836 (9th Cir. 2007). 
bed methane fields in the Powder River Basin in Montana and Wyoming. 61 The Northern Cheyenne Tribe, among others, commented that BLM should consider an additional alternative, called "phased development."62 The Ninth Circuit affirmed the district court's determination that BLM's failure to consider the tribe's proposed alternative made the EIS inadequate. ${ }^{63}$

\section{Project Modifications by Action Agencies}

A largely untold story of NEPA implementation concerns the fact that action agencies often alter or abandon projects as a result of the process itself, before litigation arises. In an early NEPA case, Justice Marshall noted that the final EIS itself, and any ensuing litigation, is only the "tip of an iceberg, the visible evidence of an underlying planning and decision making process that is usually unnoticed by the public."64 Justice Marshall was quoting from a 1975 CEQ report issued just five years after NEPA's enactment which explained that, quite apart from NEPA litigation, the NEPA process had resulted in "scores" of project changes and abandonments in that year alone. 65

The CEQ report did not address whether expert agency comments had a hand in the ultimate decision to modify or abandon projects, but it did allude to agency comments' potential to alter action agency decisions outside the context of litigation. This is no doubt because reviewing courts place considerable weight on expert agency comments. In turn, since expert agency concerns about federal proposals make action agency EAs and EISs more vulnerable in court, those comments encourage agencies to change their projects to address concerns before litigation ensues.

Case law reveals this interagency dynamic. In Greater Yellowstone $v$. Flowers, EPA raised concerns about the environmental effects of building weirs (small dams) on the Snake River as part of a plan to convert ranchland into an eighteen-hole golf course and residential area. ${ }^{66}$ Although the Tenth Circuit affirmed a district court decision that an EIS was not required, it did so because the Corps had responded to EPA's comments by adopting monitoring requirements and promising to modify or remove the weirs in the event of unacceptable environmental results. ${ }^{67}$ Greater Yellowstone is just one of many instances where expert agency comments resulted in the alteration of an action agency project to reduce adverse environmental effects.

61. Id. at 840 .

62. Id.

63. Id. at 844 .

64. Kleppe v. Sierra Club, 427 U.S. 390, 418 (1976) (Marshall, J., concurring).

65. COUNCIL ON ENVTl. QuAlity, SixTH ANNUAL RePORT 628-32 (1975) (citing projects proposed by the Department of Interior, the former Atomic Energy Commission and its successors, the Corps, the Department of Transportation, and the Department of Housing and Urban Development).

66. 359 F.3d 1257, 1275 (10th Cir. 2004).

67. Id. 
Although arguably the most "procedural" of the statutes analyzed in this Article, NEPA is far from a "paper tiger."68 In particular, expert federal agencies play a significant role in judicial review at both the EA and the EIS stage and their comments can prompt an action agency to alter its proposal even absent a court challenge. Reviewing courts can also rely on adverse comments made by expert state agencies and tribes in finding EAs or EISs inadequate. Thus, as Congress prescribed, NEPA allows expert agencies to affect substance by playing a prominent role in process.

\section{THE NHPA’s SECTION 106 CONSULTATION}

The NHPA requires federal action agencies to consider the effects of proposed projects on "any prehistoric or historic district, site, building, structure, or object included on, or eligible for inclusion on, the National Register [of Historic Places].”69 Part II explains the NHPA's decision-making structure, explains the role of expert agencies in decision making, and discusses how much authority the expert agencies have at each step in the process.

\section{A. NHPA Decision Making}

Congress passed the NHPA in 1966 to preserve properties ${ }^{70}$ of historical and cultural significance, recognizing that urban growth threatened to destroy much of this irreplaceable heritage. ${ }^{71}$ The primary mechanism Congress designed to accomplish this goal was section 106 which requires agencies to consider the effects of federal agency "undertakings" 72 on historic properties, and creates an independent federal agency, the Advisory Council on Historic Preservation (Council), to implement section 106 and comment on proposed action agency undertakings. ${ }^{73}$

Like NEPA, there are threshold requirements that trigger the NHPA's section 106 requirements: (1) the federal action agency must decide if the

68. See Calvert Cliffs' Coordinating Comm., Inc. v. U.S. Atomic Energy Comm’n, 449 F.2d 1109, 1114 (D.C. Cir. 1971) (stating that Congress did not intend NEPA to be "a paper tiger"). For a recent assessment of NEPA's effect on substantive decision making, see John Ruple \& Mark Capone, NEPA-Substantive Effectiveness Under a Procedural Mandate: Assessment of Oil and Gas EISs in the Mountain West (2015) http://ssrn.com/abstract=2585207.

69. National Historic Preservation Act, 54 U.S.C.A. § 300308 (2015). The National Register is a list of "districts, sites, buildings, structures, and objects significant in American history, architecture, archeology, engineering and culture." Authorization and Expansion of the National Register, 36 C.F.R. $\S 60.1(\mathrm{a})$ (2015).

70. Including "any prehistoric or historic district, site, building, structure, or object included on, or eligible for inclusion on, the National Register.” 54 U.S.C.A. § 300308.

71. Advisory Council on Historic Preservation, The National Historic Preservation Act 1.

72. An undertaking is "[a] project, activity, or program funded in whole or in part under the direct or indirect jurisdiction of a Federal agency, including those carried out by or on behalf of a Federal agency; those carried out with Federal financial assistance; and those requiring a Federal permit, license or approval.” Definitions in National Historic Preservation Act, 36 C.F.R. § 800.16(y) (2015).

73. 54 U.S.C.A. § 304101 (2015). 
proposed project is a federal "undertaking," a broad category which may include either federal funding or permitting; ${ }^{74}$ (2) the action agency must decide whether any "district, site, building, structure, or object included in, or eligible for inclusion in, the National Register" is present; ${ }^{75}$ and (3) the agency must determine whether the project has "potential effects" on the property. ${ }^{.6}$ Although the statute and its regulations do not expressly require consultation or comment from states, tribes, or the Council concerning the "undertaking"77 or the "potential to affect"78 questions, the regulations do require consultation with states and tribes to determine whether there are any historical properties within the scope of the project. ${ }^{79}$

If a project meets the threshold requirements, the action agency must engage in section 106 review, including an analysis of effects and an opportunity for the Council to comment. ${ }^{80}$ The NHPA imposes no requirement analogous to an EA or EIS under NEPA. Instead, the analysis of potential effects takes place as a dialogue between the action agency and consulted states, tribes, and the Council-if it decides to get involved. ${ }^{81}$ Hence the NHPA requires action agencies to consult with various parties both at the threshold stage - to determine whether its action triggers section 106-as well as analyzing the potential effects of its proposal on historic properties.

\section{B. Consultation at the Threshold Stage: Identifying Historical Properties}

Assuming there is a federal undertaking, the issue of whether there is a historical property within the project area was initially an easy question to resolve because the original section 106 applied only to properties listed in the National Register. However, in 1976 Congress complicated this threshold question by expanding section 106 requirements to properties "eligible for inclusion" in the National Register. ${ }^{82}$ NHPA regulations subsequently clarified how an action agency must determine whether a potentially affected historic

74. Initiation of the Section 106 Process, 36 C.F.R. § 800.3(a) (2015).

75. 36 C.F.R. $\S 800.16(l)(1)$. We refer to “districts, sites, buildings, structures, and objects” as “property" throughout Part II.

76. Identification of Historic Properties, id. § 800.4(a)(1) (2015).

77. Id. § 800.3(a) ("The [action] agency ... shall determine whether the proposed Federal action is an undertaking”).

78. Id. ("The [action] agency . . . shall determine whether the proposed federal action is ... a type of activity that has the potential to cause effects on historic properties.”).

79. Id. $\S 800.4(\mathrm{a})(3)$ (requiring the action agency to "[s]eek information, as appropriate, from consulting parties, and other individuals and organizations likely to have knowledge of, or concerns with, historic properties in the area, and identify issues relating to the undertaking's potential effects on historic properties”).

80. 54 U.S.C.A. § 306108 (2015) (requiring the action agency to "take into account the effect of the undertaking on any district, site, building, structure, or object that is included in or eligible for inclusion in the National Register" and to provide the Council a "reasonable opportunity to comment.”).

81. Telephone interview by Andrea Lang with Amy Cole, Senior Program Officer and Regional Attorney at The National Trust for Historic Preservation, Denver Field Office (Nov. 5, 2014).

82. 54 U.S.C.A. § 300308 (2015). 
property exists. ${ }^{83}$ The agency must consult with state historic preservation officers (SHPOs), tribal historic preservation officers (THPOs), and tribes that "attach religious and cultural significance to properties" in order to decide whether there are any eligible properties within the project's scope. ${ }^{84}$

Like NEPA, the NHPA's regulations specify that consultation with states and tribes should "commence early in the planning process." 85 Thus NHPA decision making requires consultation even at the threshold stage. Although courts typically defer to the action agency concerning the determination of the "area of potential effects," 86 consultation plays a much more significant role in determining whether there are properties with historical significance within that area.

\section{Tribal Involvement in Identifying Historical Properties}

In 1992 Congress amended the NHPA to require consultation with tribes to identify historic properties. ${ }^{87}$ NHPA regulations now require action agencies to make a "reasonable and good faith effort" to "identify historic properties

83. First, the federal action agency, in consultation with the state and and/or tribal historic preservation officer (SHPO/THPO), must identify the area of potential effects by gathering information from "consulting parties, and other individuals and organizations likely to have knowledge of, or concerns with, historic properties in the area." 36 C.F.R. § 800.4(a). Next, the action agency and consulting parties must "take the steps necessary to identify historic properties within the area of potential effects.” Id. § 800.4(b). Once the agency has identified potentially significant properties, it, along with any consulting parties, must apply the National Register criteria to decide if the property is eligible for listing. Id. § 800.4(c)(1). The criteria regard properties as historic if they: (1) are associated with historically significant events, or (2) historically significant people, (3) embody a distinctive architecture or historic style, or (4) have or may yield important historical information. The criteria also provide some potential categories of historic properties, including those associated with famous events or people; embody "distinctive characteristics of a type, period, or method of construction, or that represent the work of a master, or that possess high artistic values;" or are properties having important information about history. Criteria for Evaluation of Properties, id. § 60.4 (2015).

84. Id. § 800.4(b).

85. Participants in the Section 106 Process, id. § 800.2(c)(2)(ii)(A) (2015); Cooperating Agencies Under NEPA, 40 C.F.R. § 1501.6(a)(1) (2015) (“The lead agency shall ... [r]equest the participation of each cooperating agency in the NEPA process at the earliest possible time.”).

86. See Valley Cmty. Pres. Comm'n v. Mineta, 373 F.3d 1078, 1090-91 (10th Cir. 2004) (ruling the Federal Highway Administration's determination of the area of potential effects around a highway expansion required a high degree of administrative expertise, and was therefore entitled to substantial judicial deference); see also Safeguarding the Historic Hanscom Area's Irreplaceable Res., Inc. v. Fed. Aviation Admin., 651 F.3d 202, 215 (1st Cir. 2011) (holding Federal Aviation Administration's assessment of the area of potential effects from the construction of an aircraft service center was not arbitrary and capricious, since the agency considered alternatives and supported its findings with an investigation).

87. Reclamation Projects Authorization and Adjustment Act of 1992, Pub. L. No. 102-575, sec. 4006(a)(2), § 101(d), 106 Stat. 4755-57 (1992). This amendment was a codification of principles the National Park Service announced in "Bulletin 38," which for the first time recognized that properties with cultural significance might be eligible for inclusion in the National Register. See PATRICIA L. PARKER \& ThOMAS F. King, NAT’L PARK SERV., NAT’L REg. Bull. 38, GUIDELINES FOR EVALUATING and Documenting Traditional Cultural Properties (rev. ed. 1998), www.nps.gov/history/nr/ publications/bulletins/nrb38; see generally S. Rheagan Alexander, Tribal Consultation for Large-Scale Projects: The National Historic Preservation Act and Regulatory Review, 32 Pace L. Rev. 895 (2012). 
within the area of potential effects" in consultation with tribes. 88 Although states can and do also play a role in identifying historic properties, NHPA regulations treat tribes as possessing "special expertise," and courts have ruled that action agencies must give "special consideration" to tribal consultation in identifying historic properties. ${ }^{89}$ Notwithstanding this special role that tribes have in consultation at the identification stage, the action agency need only "make reasonable and good faith efforts" to consult. 90

For example, in Pueblo of Sandia v. United States, the Forest Service proposed a new management plan for Las Huertas Canyon in New Mexico. The plan area contained pueblo shrines and ceremonial paths which the Sandia Pueblo used to gather evergreen boughs for cultural ceremonies. ${ }^{91}$ The Forest Service mailed form letters and held meetings to request specific information about historically significant property in the project area, ${ }^{92}$ but the tribe would not provide any public information because of the "secrecy which is crucial to Pueblo religious and cultural practices,"93 although it did confidentially inform the Forest Service that a potentially eligible property existed. ${ }^{94}$ The district court ruled that the Forest Service had made a reasonable and good faith effort to identify historic property, but the Tenth Circuit reversed. ${ }^{95}$ Because the tribe notified the Forest Service of the existence of a potentially eligible property, and the Forest Service failed to investigate, the appeals court decided that the agency had not made a reasonable good faith effort and remanded to the Forest Service to comply with the NHPA. ${ }^{96}$ Moreover, because the Forest Service failed to provide the information supplied by the tribe to the SHPO, the court decided that the agency had also failed in its duty to consult with the state. ${ }^{97}$

On the other hand, some courts have been more hesitant to conclude that an action agency failed to make a reasonable good faith effort to consult with tribes in identifying historic properties. For example, in Muckleshoot Indian Tribe v. U.S. Forest Service, the Ninth Circuit reversed a district court decision

88. 36 C.F.R. $\S 800.4($ b).

89. See id. § 800.4(c)(1) ("The agency official shall acknowledge that Indian tribes and Native Hawaiian organizations possess special expertise in assessing the eligibility of historic properties that may possess religious and cultural significance to them.”); see also Quechan Tribe of Fort Yuma Indian Reservation v. U.S. Dep’t of Interior, 755 F. Supp. 2d 1104, 1109 (S.D. Cal. 2010) ("Indian tribes are entitled to special consideration in the course of an agency's fulfillment of its consultation obligations.” (emphasis in original)).

90. 36 C.F.R. § 800.4(b)(1).

91. Pueblo of Sandia v. United States, 50 F.3d 856, 857-58 (10th Cir. 1995).

92. Id. at 860 .

93. Id. at 861 .

94. Id. at 860 .

95. Id. at 857.

96. Id. See also Quechan Tribe of Fort Yuma Indian Reservation v. U.S. Dep’t of Interior, 755 F. Supp. 2d 1104, 1119 (S.D. Cal. 2010) (holding the Bureau of Land Management did not adequately consult under the NHPA because its "invitation to 'consult,' . . . amounted to little more than a general request for the Tribe to gather its own information about all sites within the area and disclose it at public meetings.”).

97. Pueblo of Sandia, 50 F.3d at 862. 
and ruled that the Forest Service adequately consulted with the Muckleshoot Tribe to identify historic property 98 affected by a proposed land exchange in Mt. Baker-Snoqualmie National Forest in Washington State. ${ }^{99}$ In an effort to identify potentially affected properties of historical or cultural significance, the Forest Service had conducted its own investigation and requested information from tribes in the area. ${ }^{100}$ Yet because the Muckleshoot Tribe claimed that the agency ignored its assertions that there were other culturally significant properties in the area, the district court decided that the Forest Service had not made a reasonable good faith effort to consult. 101

The Ninth Circuit reversed, noting that "[t]he Tribe was unable, or unwilling, to provide information sufficient to persuade the Agency that it should reconsider its decisions," and that it had missed opportunities to reveal more information to the Forest Service. ${ }^{102}$ Accordingly, the court decided that "[a]lthough the Forest Service could have been more sensitive to the needs of the Tribe," it had made a reasonable and good faith effort to identify historic properties. 103 The court distinguished Pueblo of Sandia on the ground that the Forest Service's efforts were not "as egregious" because the Forest Service "continued to seek the requested information over time" and conducted its own independent investigation, which represented a reasonable and good faith effort to identify properties. ${ }^{104}$

Consequently, although NHPA regulations indicate that tribes possess special expertise in identifying sites of historical and cultural significance, the case law suggests that tribes' ability to influence the identification of historic property is sometimes hampered by their unwillingness to disclose information about sites or their failure to comment promptly. As Pueblo of Sandia acknowledged, tribes may be "reticen[t] to disclose details of their cultural and religious practices," 105 and this desire to safeguard sites of religious and

98. $\quad$ 177 F.3d 800, 807 (9th Cir. 1999)

99. Id. at 803.

100. Id. at 806

101. Id. at 804 .

102. Id. at 806-07.

103. Id. at 807.

104. Id. See also Narragansett Indian Tribe v. Warwick Sewer Auth., 334 F.3d 161, 169 (1st Cir. 2003) (reasoning that because the Narrangensett Tribe failed to submit information on property of historic or cultural significance until after the required thirty day review period, the Warwick Sewer Authority made "reasonable [and] good faith efforts" to identify historic properties when it provided the tribe with information, engaged it about the project, and solicited its comments).

105. Pueblo of Sandia v. United States, 50 F.3d 856, 861 (10th Cir. 1995); see PARKER \& KING, supra note 87 , at 8 ("It is important to understand the role that the information being solicited may play in the culture of those from whom it is being solicited, and the kinds of rules that may surround its transmittal. In some societies traditional information is regarded as powerful, even dangerous. It is often believed that such information should be transmitted only under particular circumstances or to particular kinds of people. In some cases information is regarded as a valued commodity for which payment is in order, in other cases offering payment may be offensive. Sometimes information may be regarded as a gift, whose acceptance obligates the receiver to reciprocate in some way, in some cases by carrying out the activity to which the information pertains.”). 
cultural significance may undermine their role in NHPA consultation. To ensure that tribes play the role that Congress intended, agencies need to find ways to ensure that tribal information stays confidential and tribes must make careful cost-benefit analyses about whether to disclose it. ${ }^{106}$

\section{Deciding Eligibility for Listing in the National Register}

Once a state or tribe properly identifies a potentially significant property, NHPA regulations establish another form of consultation involving the federal Keeper of the National Register (Keeper). ${ }^{107}$ When an action agency and a state or tribe cannot agree whether an identified property meets the National Register criteria ${ }^{108}$ — or if the Council requests it — the Keeper will determine its eligibility for listing. ${ }^{109}$ The Keeper's role in determining eligibility is greater than that of expert agencies discussed so far because the Keeper applies the eligibility criteria absent any consultation. ${ }^{110}$ The Keeper, in other words, is an independent expert authority whose eligibility decisions are conclusive. 111

Assuming it decides to involve itself, the Council's role in determining whether a project is eligible for National Register listing can be crucial, since it can request a conclusive determination from the Keeper. For example, in Friends of the Atglen-Susquehanna Trail, Inc. v. Surface Transp. Board, the Surface Transportation Board (STB) permitted a rail carrier to discontinue use of a rail line that a preservation group argued was a potentially historic property eligible for listing in the National Register. ${ }^{112}$ Although the STB and the Pennsylvania SHPO had initially agreed that the rail line itself was not eligible for listing, the state later changed its position, leading the Council to request a formal determination by the Keeper. ${ }^{113}$ Yet the STB maintained that since the Keeper's determination came after a previous agreement that the rail line was ineligible, it did not have to consider the Keeper's findings. ${ }^{114}$ The Third

106. See Ethan Plaut, Tribal-Agency Confidentiality: A Catch-22 for Sacred Site Management?, 36 Ecology L.Q. 137 (2009) (outlining the scope of tribal confidentiality issues and suggesting solutions for agency and tribal practitioners).

107. The Keeper of the National Register is a National Park Service official with the authority to officially designate properties as eligible for inclusion in the National Register. Definitions in National Historic Preservation Act, 30 C.F.R. § 60.3(f) (2015).

108. See supra note 83 and accompanying text.

109. Identification of Historic Properties, 36 C.F.R. § 800.4(c)(2) (2015) ("If the agency official and the [state/tribe] do not agree, or if the Council or the [Keeper] so request, the agency official shall obtain a determination of eligibility from the [Keeper].”).

110. See supra note 107 and accompanying text.

111. See Stop H-3 Ass'n v. Coleman, 533 F.2d 434, 441 n.13 (9th Cir. 1976) (finding the Keeper's determination as to the eligibility of property for listing is conclusive); Moody Hill Farms Ltd. P'ship v. U.S. Dep't of the Interior, 205 F.3d 554, 558 (2d Cir.1999) (holding the Keeper has "independent authority" to determine whether a property should be listed as historic).

112. Friends of the Atglen-Susquehanna Trail, Inc. v. Surface Transp. Bd., 252 F.3d 246, 250-51 (3d Cir. 2001).

113. Id. at 256-57.

114. Id. at 264 . 
Circuit disagreed, 115 deciding that because the Council had brought the Keeper into the process the action agency could not ignore the Keeper's independent authority to determine the property's eligibility for listing. ${ }^{116}$

For states, tribes, and the Council, the ability to trigger the Keeper's involvement if they disagree with the action agency gives them leverage in light of the conclusive nature of the Keeper's findings. Moreover, since waiting for the Keeper's formal determination may delay projects, many action agencies give consulting parties the benefit of the doubt as to whether a property is eligible for listing. ${ }^{117}$ On the other hand, neither the Council nor the states or tribes control the Keeper's determinations. Formal determinations are also rarely requested, either because consulting parties are unaware of their ability to do so, or because threatening to or actually requesting a formal determination can antagonize other parties, making later parts of section 106 consultation more difficult. ${ }^{118}$ Although rarely requested, the involvement of the Keeper represents a kind of exogenous decision-making power that does not exist under NEPA. An entity other than the action agency possesses final decision-making authority, albeit only for the narrow decision of whether an eligible property exists.

\section{Assessing and Resolving Adverse Effects}

Like NEPA, section 106 of the NHPA is largely procedural.119 Just as NEPA forces action agencies to take a "hard look" at the effects of their proposals on the environment, 120 the NHPA requires them to "stop, look, and listen" before proceeding with a project that could affect listed or potential National Register properties.121 Once an action agency determines that its proposed "undertaking" has the potential to affect a historic property, section 106's regulations require consultation with SHPOs, THPOs, tribes, and other

115. See 28 U.S.C. § 2321(a) (2012) (granting the court of appeals jurisdiction over "proceeding[s] to enjoin or suspend, in whole or in part, a rule, regulation, or order of the Surface Transportation Board.”).

116. Friends of the Atglen, 252 F.3d at 264.

117. Interview by Andrea Lang with Jennifer Richman, Deputy District Counsel, U.S. Army Corps of Engineers Eng'rs (Oct. 22, 2014), in Portland, Oregon; see Fed. Preservation Inst., PATtERns in DETERMinATIONS OF NATIONAL REgisTeR ELIGIBILITY, 1987-2006, at 1 (2007), http://www.nps.gov /fpi/Documents/Patterns\%20in\%20DOE.pdf. ("It may . . be be that Federal agencies have chosen not to debate National Register eligibility in borderline cases, as formal determinations may delay project execution.”).

118. Richman, supra note 117.

119. Friends of the Atlgen, 252 F.3d. at 263 (holding the NHPA "is a procedural rather than a substantive statute"); but see Ruple \& Capone, supra note 68 (explaining the substantive effects of procedure).

120. Robertson v. Methow Valley Citizens Council, 490 U.S. 332, 350 (1989).

121. See Narragansett Indian Tribe v. Warwick Sewer Auth., 334 F.3d 161, 169 (1st Cir. 2003); Apache Survival Coal. v. United States, 21 F.3d 895, 906 (9th Cir. 1994). 
parties to assess whether the project will result in any adverse effects 122 and to "resolve" those effects. ${ }^{123}$ The "assess adverse effects" step is similar to NEPA's EA, while the "resolve adverse effects" step is similar to the EIS in that the goal is to develop and evaluate alternatives and mitigation measures. However, the two statutes' decision-making processes are quite different because the NHPA requires no formalized document detailing either decision. Consultation at both steps under the NHPA produces an ongoing dialogue between action agency and consulted parties rather than the formal comments and writings that occur under NEPA.

\section{Assessing Adverse Effects}

Under NHPA regulations, adverse effects exist when a project will directly or indirectly alter "any of the characteristics of a historic property that qualify the property for inclusion in the National Register in a manner that would diminish the integrity of the property's location, design, setting, materials, workmanship, feeling, or association."124 Significantly, the regulations stipulate that the action agency "shall consider" the views of "consulting parties" 125 and the public in assessing whether the project will result in an adverse effect. ${ }^{126}$ If the action agency concludes after this consultation that the project will not adversely affect the property, it issues a "finding of no adverse effect." 127 Consulting parties then have the opportunity to concur with the action agency's finding, ${ }^{128}$ resolve disagreements, or request comment from the Council. ${ }^{129}$ This authority gives consulting agencies under the NHPA power that does not exist under NEPA, which requires no concurrence.

Little case law exists on the effect of consulting parties' concurrence-or lack thereof-on action agency findings of no adverse effects. However, officials from both the Corps and the National Trust for Historic Preservation believe the concurrence power of consulting states and tribes results in better substantive outcomes for historic preservation. ${ }^{130}$ According to one participant, many action agencies consider concurrence from states and tribes a prerequisite

122. Assessment of Adverse Effects, 36 C.F.R. § 800.5(a) (2015) (requiring the action agency to "apply the criteria of adverse effect to historic properties within the area of potential effects").

123. Resolution of Adverse Effects, id. § 800.6(a) (2015) (requiring the action agency to "consult with the SHPO/THPO and other consulting parties, including Indian tribes and Native Hawaiian organizations, to develop and evaluate alternatives or modifications to the undertaking that could avoid, minimize, or mitigate adverse effects on historic properties.”).

124. Id. § 800.5(a)(1).

125. Consulting parties under the NHPA are expert agencies, including the Council, states, and tribes. Participants in the Section 106 Process. Id. § 800.2(c) (2015).

126. Id. $\S 800.5$.

127. Id. $\S 800.5(\mathrm{~b})$.

128. Id. § 800.5(c)(1).

129. Id. § 800.5(c)(2).

130. Richman, supra note 117; Cole, supra note 81. 
to moving forward on a project and will actively engage consulting parties to obtain it. ${ }^{131}$ Unlike NEPA's EA process, which can generate extensive written records, NHPA consultation involves "much more talking, and much less writing" as action agencies and consulting parties engage in an ongoing dialogue to reach agreement on the adverse effects a project is likely to have. ${ }^{132}$ This conversational approach may explain why there is little case law-there is simply not a written record for a court to review. A more positive explanation, however, is that there may be little litigation because NHPA consultation resolves many conflicts without judicial intervention. ${ }^{133}$

Where action agencies and consulting parties disagree about a finding of no adverse effects, the Council may review the action agency's finding. ${ }^{134}$ In a 1999 rule, the Council went further, giving itself final decision-making authority as to whether a project would result in an adverse effect on a historic property. ${ }^{135}$ However, in National Mining Association v. Slater, an industry group successfully challenged the rule. ${ }^{136}$ A district court held that because section 106 expressly gives substantive decision-making authority to action agencies, the Council could not use a regulation to effectively reassign that authority to itself. 137 Consequently, current NHPA regulations only allow the Council to issue an advisory opinion to the action agency if it disagrees with its finding of no adverse effects. ${ }^{138}$ Final decision-making authority on the adverse effects of proposed actions remains with the action agency. 139

\section{Resolving Adverse Effects}

If the action agency determines that the project will result in adverse effects to a historic property, it must engage consulting parties to "develop and evaluate alternatives or modifications to the undertaking that could avoid, minimize, or mitigate adverse effects." 140 Although conceptually similar to the NEPA process, this duty to evaluate alternatives is in practice quite different.

131. Cole, supra note 81

132. Id.

133. Richman, supra note 117.

134. 36 C.F.R. § 800.5(c)(2)(ii).

135. Protection of Historic Properties, 61 Fed. Reg. 48,580 (Sept. 13, 1996) (codified at 36 C.F.R. $\S 800.4(d)(2)(1999))$.

136. 167 F. Supp. 2d 265, 287 (D.D.C. 2001), rev'd on other grounds sub nom. Nat'l Min. Ass'n v. Fowler, 324 F.3d 752 (D.C. Cir. 2003).

137. Id. ("Making [a no adverse effects determination], however, is the one substantive role that is expressly delegated to the agency in section 106 of the Act. [The Council's regulations] thereby enable the Council to interfere directly with the agency's responsibility in this respect, and as such, they are impermissible substantive regulations.”).

138. 36 C.F.R. $\S 800.5(\mathrm{c})(3)(\mathrm{i})$.

139. Id. § 800.5(c)(3)(ii)(B).

140. Resolution of Adverse Effects, id. § 800.6(a) (2015). The action agency must also notify the Council of its continuing consultation, id. $\S 800.6(\mathrm{a})(1)$, provide documentation of the consultation process, id. § 800.6(a)(3), and as notify and provide documentation to the public, id. § 800.6(a)(4). The Council may join the consultation process if it wishes, or if the action agency requests. Id. 
Like the NHPA's assessing adverse effects stage, it involves much less documentation than NEPA requires. ${ }^{141}$ If the consulting parties do not concur with the action agency on how to resolve adverse effects and sign a memorandum of agreement to that effect, consultation "terminates" and the Council issues a formal comment, which the action agency must take into account before reaching a final decision on the undertaking. ${ }^{142}$ The effect of this comment is similar to that of an expert agency comment under NEPA, in that the action agency must carefully consider and explain any divergence from Council opinion. ${ }^{143}$ Also like NEPA, the resolution of adverse effects is not binding on the action agency, which retains ultimate decision-making authority. 144

As with concurrence on a no adverse effects finding, the lack of case law on the effect of consulting parties' concurrence may reflect the NHPA's efficacy. According to NHPA participants at the Corps and the National Trust for Historic Preservation, few projects receive a formal Council comment because of the political "black mark" that results from terminating consultation. ${ }^{145}$ Further, in most cases, action agencies would rather come to some kind of agreement through dialogue with consulting agencies than face the time and expense of seeking and waiting for a formal Council comment. ${ }^{146}$ Hence consulting expert agencies under the NHPA appear to have the bargaining power to leverage action agencies into adopting favorable alternatives or mitigation. ${ }^{147}$

141. Under NHPA regulations, the outcome of consultation at this stage is a Memorandum of Agreement (MOA), in which the consulting parties agree to a particular course of action to resolve the adverse effects. Id. § 800.6(b)(1). The only consulting parties which must sign the MOA are the lead agency official, the SHPO/THPO, and (if it has joined the consultation process) the Council. Id. Other consulting parties, called "invited signatories," do not need to sign the MOA to complete the "resolution of adverse effect" process. Unlike at other stages of the NHPA process, consulting tribes play a lesser role than SHPOs/THPOs and are not required signatories. Id. § 800.6(c)(2). The MOA "evidences the agency official's compliance with section 106 and ... govern[s] the undertaking and all of its parts.” Id. $\S 800.6(\mathrm{c})$.

142. Failure to Resolve Adverse Effects, id. § 800.7 (2015).

143. See Citizens Alliance, Inc. v. Slater, 176 F.3d 686, 696 (3d Cir. 1999) (“‘A] federal agency undertaking a project affecting historic properties is not obligated to give the [Council's] opinion so much weight that it is foreclosed from making its own decision, though it must make clear in the record that the [Council's] comments were taken seriously").

144. See Effects of Listing Under Federal Law, 36 C.F.R. § 60.2(a) (2015) ("While the Advisory Council comments must be taken into account and integrated into the decision-making process, [final] decisions rest with the agency implementing the undertaking."); see also Waterford Citizens Ass'n v. Reilly, 970 F.2d 1287,1290 (4th Cir. 1992) (“[The] procedural regulatory scheme guides agencies contemplating a project.... The final outcome of that process, however, demonstrates the limited obligation of the agency.”).

145. Richman, supra note 117; Cole, supra note 81.

146. Richman, supra note 117 .

147. A preferred mitigation measure of an action agency may be to make a movie or exhibit to preserve the historical significance of an adversely affected property, while a consulting party may prefer that the agency promise to save or restore another similar property. Whether to pursue one or both of the methods depends on negotiations between the agency and consulting parties as the agency attempts to convince the parties to sign the memorandum of agreement. Cole, supra note 81. 


\section{The ESA’s Federal CONSULtATION Under SECTION 7}

Section 7 of the ESA, a statute that has been called the "pit bull" of environmental law, 148 requires that federal agencies engaged in actions likely to adversely affect listed species consult with either the FWS or the National Marine Fisheries Service (NMFS) (collectively "Services") ${ }^{149}$ to ensure that proposed actions do not "jeopardize" the species' continued existence or damage their critical habitat. ${ }^{150}$ This Part explores the effect of the Services' opinions during ESA consultation. As under NEPA, expert agency involvement creates a record that often makes it more difficult for a court to defer to an action agency's unilateral choices. Moreover, the ESA's structure and the role of the Services under the statute make the effect of their opinions more determinative than those of expert agencies under either NEPA or the NHPA.

\section{A. ESA Consultation Overview}

Before exploring the effects of federal consultation under the ESA, a brief explanation of how consultation requirements are triggered is necessary because, as with the statutes discussed above, avoiding consultation provides a safe harbor for an action agency. The ESA requires action agencies to consult the relevant Service when two threshold requirements are met: (1) there is a discretionary agency action, ${ }^{151}$ and (2) the action "may affect" a listed species or critical habitat. 152

The statute defines the first triggering requirement of "agency action" broadly to include any action "authorized, funded, or carried out" by any federal agency. ${ }^{153}$ Courts have recognized that there is "little doubt" that Congress intended "agency action" to have broad applicability. 154 However, ESA regulations confine the definition of "agency action" to those actions that are discretionary, 155 a view the Supreme Court upheld in National Association of Homebuilders $v$. Defenders of Wildlife. ${ }^{156}$ The ESA discretionary act

148. See Nathan Baker, Water, Water, Everywhere, and at Last a Drop for Salmon? NRDC v. Houston Heralds New Prospects Under Section 7 of the Endangered Species Act, 29 ENVTL. L. 607, 613 (1999) (quoting Donald Barry, Assistant Secretary for Fish, Wildlife, and Parks of the Department of Interior).

149. For effects on listed terrestrial and freshwater species, the action agency must consult with FWS; for effects on listed marine and anadromous species, the action agency must consult with NMFS.

150. 16 U.S.C. $\S 1536$ (2012).

151. 50 C.F.R. § 402.03 (2014).

152. Id. § 402.14(a) (2014).

153. 16 U.S.C. § 1536(a)(2).

154. See, e.g., Karuk Tribe of Cal. v. U.S. Forest Serv., 681 F.3d 1006, 1020 (9th Cir. 2012).

155. 50 C.F.R. $\S 402.03$.

156. 551 U.S. 644, 673 (2007). In Homebuilders, environmental groups challenged EPA's approval of the State of Arizona to administer the National Pollutant Discharge Elimination System (NPDES) program under the CWA. Id. at 654-55. EPA argued that because the statute required it to hand over NPDES permitting authority, its action was nondiscretionary, and thus no consultation with the Services was necessary. Id. at 654. The Supreme Court agreed with EPA, deferring to the regulation as a reasonable interpretation of section 7 of the ESA. Id. at 673 . 
requirement is therefore similar to NEPA's, which also requires an agency action to be discretionary to trigger the statute's procedural requirements. ${ }^{157}$

The second triggering requirement, that the action "may affect" a listed species, requires the action agency to determine whether there are any listed species or critical habitat within the scope of the proposed action. ${ }^{158}$ Once the action agency has formally requested information from the relevant Service, it must determine whether its proposal "may affect" that species or its critical habitat. 159 To avoid consultation, the action agency must conclude that its action will have no effect on any species or critical habitat within the project area. However, at least in the Ninth Circuit, the "may affect" threshold is a low bar, including "[a]ny possible effect, whether beneficial, benign, adverse or of an undetermined character." 160 Therefore although an action agency can avoid consulting with the Services by simply concluding its action will have no effect on any listed species, that finding may be vulnerable to challenge in court. 161

Once an agency action triggers consultation, the agency must consult with the relevant Service through either formal or informal consultation. In informal consultation, which - much like an EA under NEPA—determines the need for formal consultation, an action agency assesses the likely effect of its actions on listed species. ${ }^{162}$ If the agency determines that the action is "not likely to adversely affect" a listed species or critical habitat, the Service must concur with that determination in order for the project to proceed without formal consultation. ${ }^{163}$ Without concurrence, the action agency must initiate formal

157. See Dep’t of Transp. v. Pub. Citizen, 541 U.S. 752, 770 (2004) (“[B]ecause [the Federal Motor Carrier Safety Administration] ha[d] no discretion to prevent the entry of Mexican trucks, its EA did not need to consider the environmental effects arising from the entry.”).

158. 16 U.S.C. $\S 1536(c)(1)$.

159. 50 C.F.R. § 402.14(a) (2014).

160. Karuk Tribe of Cal. v. U.S. Forest Serv., 681 F.3d 1006, 1027 (9th Cir. 2012) (quoting California ex rel. Lockyer v. U.S. Dep’t of Agric., 575 F.3d 999, 1018 (9th Cir. 2009)). In Karuk Tribe, the Forest Service approved several dredge mining activities in the Klamath River Basin without engaging in consultation, explaining that the mining would have no effect on either endangered coho salmon or coho salmon critical habitat in the area. Id. at 1013. The federal district court did not reach the "may affect" question, deciding that the Forest Service's approval of the mining activities did not constitute "agency action" under the ESA, and a divided panel of the Ninth Circuit affirmed. Id. at 1017. However, an en banc Ninth Circuit reversed, ruling that the Forest Service's approval was a final agency action, and that because the mining could affect coho salmon or their habitat, the activities met the "may affect” threshold. Id. at 1029; but see Newton Cnty. Wildlife Ass'n v. Rogers, 141 F.3d 803, 811 (8th Cir. 1998) (upholding the Forest Service's conclusion that timber sales and associated road construction would have no effect on listed bald eagles).

161. See 50 C.F.R. § 402.03 (2014); see also Interagency Cooperation-Endangered Species Act of 1973, as Amended; Final Rule, 51 Fed. Reg. 19,926 (June 3, 1986) ("The threshold for formal consultation must be set sufficiently low to allow Federal agencies to satisfy their duty to 'insure' under section 7(a)(2). Therefore, the burden is on the Federal agency to show the absence of likely, adverse effects to listed species or critical habitat as a result of its proposed action in order to be excepted from the formal consultation obligation.”).

162. The agency either analyzes potential effects in a biological assessment if the action also qualifies as a "major construction activity" under NEPA, 50 C.F.R. § 492.12 (2015), or by way of informal communications with the Services. Id. § 402.13 (2015).

163. Id. § 402.14(b)(1). 
consultation, ${ }^{164}$ culminating in a biological opinion (BiOp) from the relevant Service that determines whether the proposed action is likely to jeopardize the continued existence of a listed species. 165 There are consequently two decisions the Services can make that affect an action agency's ability to proceed with a project: (1) a concurrence or nonconcurrence in informal consultation, and (2) a "jeopardy" or "no jeopardy" finding in a BiOp.

\section{B. The Effect of Informal Consultation}

Because the Services must concur with an action agency's "not likely to adversely affect" decision, the Services have the final say on whether to proceed to formal consultation. The fact that action agencies must obtain their concurrence makes the Services' role under the ESA more powerful than consulting agencies under the NHPA, whose concurrence is not required. 166 Moreover, even if the relevant Service concurs with a not likely to adversely affect decision, action agencies must reinitiate consultation under certain circumstances. 167

The requirement that the Services concur with the action agency during informal consultation gives them significant leverage. Because of the time and resource costs of preparing a BiOp under formal consultation, action agencies strongly prefer to stick to informal consultation. The threat of having to engage in formal consultation and wait for a BiOp gives the Services the ability to trade their concurrence for changes in the design of the project. 168 Thus, what seems like a purely procedural requirement can in fact produce substantive project changes. This ability to affect substance through process makes the ESA quite similar to NEPA and the NHPA. ${ }^{169}$

Given the Services' leverage, it is perhaps unsurprising that the Bush administration twice unsuccessfully attempted to eliminate the need for a

164. Id. § 402.14(a).

165. Id. § 402.14(g)(4).

166. Under the NHPA, consultation may always be "terminated," and the action agency can proceed once it has received an advisory comment from the Council. Although action agencies in practice will seek to avoid this outcome, see supra notes 142-144 and accompanying text, the concurrence is nevertheless inconclusive under the NHPA. See supra note 141 and accompanying text.

167. The effect of a concurrence concludes an action agency's ESA obligations only as long as (1) no "new information reveals effects of the action that may affect listed species or critical habitat in a manner or to an extent not previously considered," (2) there is not modification to the action "that causes an effect to the listed species or critical habitat that was not considered ....”, and (3) no "new species is listed or critical habitat designated that may be affected by the identified action." 50 C.F.R. § 402.16(b)(d) (2014). Although by its terms this regulation applies only to formal consultation, the Ninth Circuit applied it to informal consultation in Forest Guardians v. Johanns, 450 F.3d 455, 458 (9th Cir. 2006) (requiring the Forest Service to reinitiate consultation because it failed to adhere to criteria established during informal consultation).

168. See Daniel J. Rohlf, The Endangered Species Act at Forty: The Good, the Bad, and the Ugly, 20 ANIMAL L. 251, 265-66 (2014).

169. See supra Parts II (NEPA) and III (NHPA). 
Service concurrence by promulgating "counterpart" regulations. ${ }^{170}$ In 2003, as a part of the Healthy Forests Initiative, ${ }^{171}$ the Services sought to allow "alternative consultation agreements" 172 to satisfy the section 7 consultation requirement for actions under the National Fire Plan. ${ }^{173}$ Then, less than a year later, the Services attempted to promulgate regulations that would have allowed EPA and the Department of Agriculture to use alternative consultation agreements for actions under the Federal Insecticide, Fungicide, and Rodenticide Act (FIFRA). ${ }^{174}$ Both sets of regulations would have authorized action agencies to make a unilateral not likely to adversely affect determination under certain circumstances, ${ }^{175}$ removing the need for a concurrence from the Services.

Courts struck down both sets of regulations. In 2006's Washington Toxics Coalition v. U.S. Department of the Interior, a federal district court decided that the FIFRA regulations were inconsistent with the plain language of the ESA. ${ }^{176}$ The court explained that because "the 'in consultation with' language [in the ESA] is paired with 'with the assistance of the Secretary,' ... [a not likely to adversely affect] determination is not to be unilaterally made." 177 Six years later, in Defenders of Wildlife v. Salazar, the federal district court for the District of Columbia struck down the National Fire Plan's counterpart regulations, although on narrower grounds. ${ }^{178}$ The administration had justified the regulations on the ground that the length of consultation for important firerelated projects "encumbered" action agencies. But the court decided that the adoption of the regulations was arbitrary because "[t]here [was] no explanation in the Regulations as to how the biologists ... [were] being 'encumbered'; [and] no examples of instances in which Fire Plan projects were delayed

170. 50 C.F.R. § 402.04 (2014).

171. White House, Healthy Forests: An Initiative for WildFire Prevention and STRONGER COMMUNITIES (2002), http://www.fs.fed.us/projects/documents/HealthyForests_Pres_Policy \%20A6_v2.pdf; see generally Jesse B. Davis, The Healthy Forests Initiative: Unhealthy Policy Choices in Forest and Fire Management, 34 ENVTL. L. 1209 (2004).

172. Under an alternative consultation agreement, as long as action agencies receive training adequate to make "not likely to adversely affect" determinations, the Services could allow the action agency to make that decision.

173. Joint Counterpart Endangered Species Act Section 7 Consultation Regulations, 68 Fed. Reg. 68,254 (Dec. 8, 2003) (codified at 50 C.F.R. pt. 402, subpt. C).

174. Joint Counterpart Endangered Species Act Section 7 Consultation Regulations, 69 Fed. Reg. 47,732 (Aug. 5, 2004) (codified at 50 C.F.R. pt. 402, subpt. D).

175. The FIFRA counterpart regulations allowed alternative consultation agreements for discretionary EPA actions under FIFRA. 50 C.F.R. § 402.42(a) (2014). The Healthy Forest regulations authorized such agreements for National Fire Plan projects. 50 C.F.R. § 402.33(a) (2014).

176. 457 F. Supp. 2d 1158, 1180 (W.D. Wash. 2006).

177. Id. at 1179 .

178. 842 F. Supp. $2 d 181$ (D.D.C. 2012), appeal dismissed, No. 12-5111, 2012 WL 2371618 (D.C. Cir. June 21, 2012). 
because of the 'encumbrances' that biologists faced in deciding whether to concur."179

These two decisions leave the fate of future attempts to create counterpart regulations unclear. The ESA's implementing regulations still authorize counterpart regulations, ${ }^{180}$ but even these provisions may not survive judicial review. If a reviewing court adopts the Washington Toxics court's interpretation of the language of the ESA consultation requirements, ${ }^{181}$ it will likely strike down future attempts to give decision-making authority entirely over to an action agency. On the other hand, if a court were to take the Defenders of Wildlife approach, the agencies may be able to rationally justify counterpart regulations in order to avoid delays in project approvals due to wildlife agency concurrences. ${ }^{182}$ These failed regulatory efforts underscore the importance of the Services' concurrence authority - the mere threat of formal consultation gives them considerable influence over the ESA process.

\section{The Effect of Formal Consultation}

Formal consultation concludes when the relevant Service issues a BiOp that determines whether the action agency's proposal will jeopardize the continued existence of a listed species. The Service's jeopardy determination imposes one of two sets of duties on the action agency depending on whether or not the Service finds "jeopardy."

\section{The Effect of a "No Jeopardy" Finding}

A Service's "no jeopardy" finding does not conclude an action agency's ESA obligations. Because the statute leaves the final responsibility for ESA compliance with the action agency, not the Services, ${ }^{183}$ an action agency's decision to rely on a "no jeopardy" BiOp must not be arbitrary and capricious. ${ }^{184}$ Courts have made clear that an action agency may not "simply

179. Id. at 186. An additional reason the court gave for striking down the 2003 regulations was that they failed to define what constitutes a "National Fire Plan project." Id. at 187.

180. 50 C.F.R. $\S 402.04$ (2014).

181. See supra notes $176-177$ and accompanying text.

182. See supra notes $178-179$ and accompanying text.

183. 16 U.S.C. § 1536(a)(2) (2012) ("The agency shall, in consultation with and with the assistance of [the Services], insure that any action ... . is not likely to jeopardize the continued existence of [a listed] species.” (emphasis added)).

184. City of Tacoma v. Fed. Energy Regulatory Comm’n, 460 F.3d 53, 75 (D.C. Cir. 2006) (ruling FERC's reliance on a "no jeopardy" BiOp was not arbitrary or capricious because it had no additional information that the Service did not have, and "expert agencies are in the best position to make discretionary factual determinations about whether a proposed agency action will create a problem for a listed species and what measures might be appropriate to protect the species."); see also Dow AgroSciences L.L.C. v. Nat'l Marine Fisheries Serv., 637 F.3d 259, 266 (4th Cir. 2011) ("When a court of appeals reviews the EPA's reliance on a BiOp, it ... determine[s] . . . whether the EPA's reliance was arbitrary and capricious.”). 
rubber stamp ... the [Service]'s analysis."185 At the same time, however, an action agency "need not undertake a separate, independent analysis." 186 In fact, according to the Ninth Circuit, "even when the [Service's] opinion is based on 'admittedly weak' information, another agency's reliance on that opinion will satisfy its obligations under the ESA if a challenging party can point to no 'new' information." 187 Consequently, although the action agency has ultimate responsibility for ESA compliance, a "no jeopardy" finding by the relevant Service is strong evidence that a project will comply with the ESA.

\section{The Effect of a "Jeopardy" Finding}

From a strictly legal perspective, the effect of a "jeopardy" finding on an action agency's ability to continue a project is similar to that of a "no jeopardy" finding. When an action agency relies on a Service's "jeopardy" finding, a reviewing court will apply the same standard as for a "no jeopardy" finding, 188 meaning that an action agency need not conduct its own independent review to determine if the jeopardy analysis is accurate. ${ }^{189}$ As long as no party presents new information, an action agency may properly rely on the Service's finding. 190

From a practical perspective a "jeopardy" finding is quite differentaction agencies have a difficult time proceeding with a project. Writing for a unanimous Supreme Court in Bennett v. Spear, Justice Scalia proclaimed that "jeopardy" findings are "virtually determinative" and that while a BiOp "theoretically serves an 'advisory function,' in reality it has a powerful coercive effect on the action agency." 191 Thus while the ESA technically places final decision-making authority in the action agency's hands, ${ }^{192}$ in practice it may be impossible to articulate sufficient reasons for disregarding the expert Service's BiOp to survive judicial review. ${ }^{193}$ BiOps' virtually determinative effect under the ESA therefore appears to give the Services a much larger substantive role in decision making than their counterpart expert agencies have under NEPA and

185. Aluminum Co. of America v. Bonneville Power Admin., 175 F.3d 1156, 1161 (9th Cir. 1999); see Pyramid Lake Paiute Tribe of Indians v. U.S. Dep’t of Navy, 898 F.2d 1410, 1415 (9th Cir. 1990) ("A federal agency cannot abrogate its responsibility to ensure that its actions will not jeopardize a listed species; its decision to rely on a FWS [BiOp] must not have been arbitrary or capricious.").

186. Aluminum Co., 175 F.3d at 1161 (rejecting an industry challenge to the Bonneville Power Administration's reliance on a NMFS "jeopardy" BiOp and deciding that reliance on a "jeopardy” BiOp should receive the same judicial deference on review as reliance on a "no jeopardy" $\mathrm{BiOp}$ ).

187. Pyramid Lake, 898 F.2d at 1415; see City of Tacoma, 460 F.3d. at 76 (adopting the Pyramid Lake court's interpretation and applying it to conclude that FERC reasonably relied on a FWS BiOp because the challenging party presented no new information).

188. Aluminum Co., 175 F.3d at 1161.

189. Id.

190. Id.

191. 520 U.S. 154, 169-70 (1997) (ruling that the plaintiffs had standing because their injuries were fairly traceable to the FWS due to the coercive effects of BiOps on action agencies).

192. 16 U.S.C. § 1536(a)(2) (2012).

193. Bennett, 520 U.S. at 169-70. 
the NHPA. Although all three statutes rely on judicial review (or the threat of it) to affect action agency decisions, the likelihood that a court will side with the expert agency appears greater under the ESA than the other two statutes.

\section{THE ClEAN WATER ACT’s SECTION 404(C) EPA Veto}

Unlike the three statutes examined above, section 404(c) of the CWA gives direct decision-making power to an expert agency, EPA, in the context of permits issued by the Corps. This Part first explains the dynamics of EPA's authority under section 404(c) to veto Corps-issued permits for the discharge of dredged or fill material, and then discusses the limits of that authority. It then explains how the CWA's delegation of final decision-making authority gives EPA more power to affect an action agency's decisions than any of the statutes explored so far.

\section{A. The Scope of EPA's CWA Section 404 Veto Authority}

Section 404 of the CWA authorizes the Corps to issue permits 194 "for the discharge of dredged or fill material into the navigable waters at specified disposal sites." 195 However, EPA has authority to veto Corps permits if it determines that the discharge in question "will have an unacceptable adverse effect on ... water suppl[y], [fish and] wildlife, or recreation."196 The statute on its face clearly gives EPA the last word on the Corps' permitting, although EPA vetoes are subject to public notice and comment, as well as consultation with the Corps. ${ }^{197}$ The courts have also broadly interpreted both why EPA may veto section 404(c) permits and when it may do so, although they have raised questions about the breadth of the CWA's jurisdiction, which may affect where EPA's veto authority applies in the future. 198

Courts have consistently deferred to EPA on the factors it may consider in its section 404(c) veto decisions. 199 Since section 404(c)'s "unacceptable

194. The statute also authorizes EPA to grant states section 404 permitting authority for waters that are not traditionally navigable if the state meets certain requirements, 33 U.S.C. § 1344(g)-(h) (2012), although only Michigan and New Jersey have assumed this authority. 40 C.F.R. §§ 233.70, 233.71 (2015).

195. Clean Water Act, 33 U.S.C. § 1344(a). The statute exempts discharges from "normal farming, silviculture, and ranching activities such as plowing, seeding, cultivating, minor drainage, harvesting for the production of food, fiber, and forest products, or upland soil and water conservation practices.” Id. § 1344(f)(1)(A). A 2014 guidance document issued by the Corps and EPA attempted to interpret the "normal farming" exception, but Congress intervened, ordering the agencies to withdraw it in the 2015 Appropriations Act. Consolidated and Further Continuing Appropriations Act, 2015, Pub. L. No. 113235, § 112, 128 Stat. 2129, 2308 (2014).

196. 33 U.S.C. § 1344(c). For a brief history of the implementation of section 404, see Amy Oxley, No Longer Mine: An Extensive Look at the Environmental Protection Agency's Veto of the Section 404 Permit Held by the Spruce No. 1 Mine, 36 S. ILL. U. L.J. 139, 143-47 (2011).

197. 33 U.S.C. § 1344(c).

198. See supra notes $217-220$ and accompanying text.

199. See Michael C. Blumm \& Elisabeth D. Mering, Vetoing Wetland Permits Under Section 404(c) of the Clean Water Act: A History of Inter-Federal Agency Controversy and Reform, 33 U.C.L.A. 
adverse effects" standard includes no statutory definition, EPA has relied on section 404(b)(1)'s guidelines, ${ }^{200}$ which the CWA requires the Corps to use in issuing permits. ${ }^{201}$ However, EPA is not required, as the Corps is, 202 to balance environmental concerns against "public interest" factors that may favor issuing the permit. ${ }^{203}$ Thus, while the Corps' "public interest review" may allow economics to trump environmental concerns, EPA's veto power allows it to overturn the Corps' permit decisions based solely on environmental concerns.

A related issue is how far EPA's veto power extends temporally. The D.C. Circuit addressed this question in 2013's Mingo Logan Coal Co. v. EPA. ${ }^{204}$ In that case, the Corps issued a permit in 2007 to a coal company for fill discharges in connection with its mountaintop mining operations in West Virginia. ${ }^{205}$ EPA did not exercise its veto authority until 2011, four years after the Corps issued the permit. ${ }^{206}$ The district court decided that section 404(c) did not authorize EPA to revoke existing permits, ${ }^{207}$ but the D.C. Circuit reversed, focusing on the text of section 404(c), which expressly authorizes EPA to veto "whenever" it finds an unacceptable adverse effect.208 Consequently, the court concluded that section 404 "imposes no temporal limit on [EPA's] authority" to veto a Corps permit. 209

The D.C. Circuit's decision has led some to wonder whether EPA possesses prospective veto power as well. ${ }^{210}$ Section 404(c)'s regulations have

J. ENVTL. L. \& POL'Y (forthcoming 2015) (supplying a detailed history of the thirteen section 404(c) vetoes over the last four decades).

200. The section 404(b)(1) guidelines prohibit the Corps from issuing a section 404 permit when (a) there is a practicable alternative available that would have a less adverse effect on the ecosystem, (b) the proposed discharge will violate state water quality standards, toxic effluent standards, the ESA, or fail to protect marine sanctuaries under the Marine Mammal Protection Act, (c) the proposed discharge will "cause or contribute to significant degradation of the waters of the United States," or (d) the applicant has not taken "appropriate and practicable steps [which would] minimize potential adverse impacts of the discharge on the aquatic ecosystem" 40 C.F.R. § 230.10 (2015).

201. See Bersani v. EPA, 674 F. Supp. 405, 414 (N.D.N.Y. 1987), aff'd, 850 F.2d 36 (2d Cir. 1988) (holding that EPA's decision to rely on section 404(b)(1) guidelines to determine an "unacceptable adverse effect" under section 404(c) was a reasonable interpretation of the statute).

202. The Corps' regulations have long imposed a "public interest review" on the agency under which the "benefits which reasonably may be expected to accrue from the proposal must be balanced against its reasonably foreseeable detriments.” 33 C.F.R § 320.4 (2015).

203. See James City Cnty. v. EPA, 12 F.3d 1330, 1336 (4th Cir. 1993) (ruling that EPA did not need to consider the need of the public for water before vetoing a permit to construct a dam and reservoir, and may base its veto solely on environmental harms).

204. Mingo Logan Coal Co. v. EPA, 714 F.3d 608, 613 (D.C. Cir. 2013), cert. denied, 134 S. Ct. 1540 (2014).

205. Id. at 610 .

206. Id. at 611 .

207. Mingo Logan Coal Co. v. EPA, 850 F. Supp. 2d 133, 153 (D.D.C. 2012), rev'd, 714 F.3d 608 (D.C. Cir. 2013).

208. Mingo Logan, 714 F.3d at 613 (emphasis in original) (quoting 33 U.S.C. § 1344(c) (2012)).

209. Id.

210. See, e.g., Lisa A. Kirschner, EPA's Clean Water Act Section 404 Veto Authority, 28 NAT. RES. \& ENV’T 54, 54-55 (2013). 
recognized such vetoes since 1979,211 although EPA has seldom exercised this authority. However, EPA appears poised to preemptively veto the controversial Pebble Mine Project-a proposed gold and copper mine in Alaska's Bristol Bay watershed - even though the proponent has yet to file a permit application. In mid-2014 EPA issued a notice of proposed determination 212 that it would prospectively restrict (veto) discharges associated with the mine that would result in a loss of streams, a loss of wetlands, lakes or ponds, or alter streamflow. ${ }^{213}$ After a public comment period that generated some 155,000 comments, the agency promised a decision in 2015,214 although that decision has been delayed by a preliminary injunction. ${ }^{215}$ All this has not gone unnoticed. The threat to the Pebble Mine Project, coupled with the judicial affirmation of EPA's veto power in Mingo Logan, has led critics to call on Congress to amend the CWA to impose a temporal limit on EPA's veto authority. 216

EPA's authority extends only as far as the Corps' CWA jurisdiction-if the Corps cannot issue a permit, EPA cannot veto it. ${ }^{217}$ Still, both agencies take

211. 40 C.F.R. § 231.1(a) (2015) (“[EPA] may also prohibit the specification of a site under section 404(c) with regard to any existing or potential disposal site before a permit application has been submitted to or approved by the Corps or a state.").

212. EPA, Proposed Determination of the U.S. Environmental Protection Agency Region 10 Pursuant to Section 404(c) of the Clean Water Act: Pebble Deposit Area, Southwest Alaska ES-5-ES-6 (2014).

213. The notice of proposed determination contains numerical limits on the loss of streams, wetlands, and streamflow alterations. See id.

214. Announcement to Extend the Period to Evaluate Public Comments Received on the Proposed Determination for the Pebble Deposit Area, Southwest Alaska, 79 Fed. Reg. 56,365 (Sept. 19, 2014).

215. The Alaska federal district court issued a preliminary injunction preventing EPA from making a final section 404(c) decision until it can rule on a Federal Advisory Committee Act claim. See Bristol Bay Native Corp., Court Issues Injunction Delaying EPA process on Pebble, PEBBLE WATCH (Nov. 24, 2014, 7:07 PM), http://www.pebblewatch.com/index.php/645-pebble-injunction-upheld-by-federaljudge. The case arose from EPA's failure to disclose certain information, not a challenge to EPA's veto authority generally. If EPA proceeds to exercise its veto authority, the agency will face an almost certain court challenge as to whether it may veto a project with neither a permit application nor an issued permit. In fact, the company proposing the mine already challenged EPA's authority to veto the project, but because EPA had not yet issued a final determination, the court held there was no "final agency action” available for judicial review. JosePH L. JENKINS ET AL., AMERICAN BAR AsSOCIATION, ABA ENVIRONMENT, ENERGY, AND RESOURCES LAW: THE YEAR IN REVIEW 169 (2014).

216. See, e.g., Oxley, supra note 196, at 140 ("[C]hanges must be made to section 404 to limit the EPA's ability to veto existing permits, to encourage the agency to act before a permit is issued, and to instill trust in the current permitting system.”); Jason Bailey, Clean Water Act, Section 404 Applicants: May the Odds Be Ever in Your Favor, 3 AM. U. Bus. L. Rev. 457, 485 (2014) ("Congress should provide additional guidance as to how and when the EPA can invoke its section 404(c) veto power.”). On February 11, 2015, Congressman Bob Gibbs of Ohio introduced a bill that would restrict EPA's veto authority to after the Corps has processed an application and before it issues a final permit. Regulatory Certainty Act of 2015, H.R. 896, 114th Cong. (2015).

217. The CWA gives the Corps and EPA jurisdiction over "navigable waters," statutorily defined as "waters of the United States." 33 U.S.C. § 1362(7) (2012). According to the Supreme Court's fractured decision in Rapanos v. United States, wetlands must have a surface connection (according to the plurality opinion) or a "significant nexus" (Justice Kennedy's decisive concurrence) to navigable-infact waters to fall within the statute. 547 U.S. 715, 742, 767 (2006). Although EPA released guidance 
an expansive view of their jurisdiction. In May 2015 EPA and the Corps promulgated a definitional rule that categorically includes all tributaries and all waters adjacent to them as within the CWA's jurisdiction. ${ }^{218}$ Although the Corps and EPA claimed that the rule in fact narrows the scope of CWA jurisdiction by adding more regulatory exemptions, ${ }^{219}$ in practice it will likely make it easier for the Corps and EPA to assert jurisdiction over more areas without having to undertake a fact-intensive analysis. ${ }^{220}$ That will save administrative resources, so even if the rule does not technically expand the agency's jurisdiction, it could shift personnel from making jurisdictional determinations to enforcement, including use of EPA's veto authority.

\section{B. The Effect of the EPA's Veto Power on Corps Decision Making}

The most obvious way for EPA to affect a Corps permit is to veto it, thereby prohibiting a permit applicant from discharging dredged or fill material. This authority gives EPA the last administrative word on the permit decision, ${ }^{221}$ distinguishing section 404(c) from statutes like NEPA, the NHPA, and the ESA, where the final decision remains in the hands of the action agency. 222

Despite EPA's apparently broad authority to veto permits, it has exercised this power only thirteen times in the forty-three years since Congress enacted section 404, and (somewhat surprisingly) just three times since 1990.223 Nevertheless, the threat of an EPA veto provides leverage akin to that exercised by the Services in ESA consultation. In fact, a threat under the CWA is likely

concerning how to determine whether a water is jurisdictional, the result of Rapanos is that jurisdictional determinations often require fact-intensive case-by-case analyses. See Sackett v. EPA, 132 S. Ct. 1367, 1375 (2012) (Alito, J., concurring) ("Far from providing clarity and predictability, the agency's latest informal guidance advises property owners that many jurisdictional determinations concerning wetlands can only be made on a case-by-case basis by EPA field staff.").

218. Clean Water Rule: Definition of "Waters of the United States," 80 Fed. Reg. 37,054, 37,058 (June 29, 2015) (amending 33 C.F.R. pt. 328, 40 C.F.R. pt. 117).

219. Id. at 37,054 .

220. However, a district court in North Dakota has granted a preliminary injunction on enforcement of the rule in thirteen states, deciding that EPA likely exceeded its congressional grant of authority in promulgating it. N. Dakota v. U.S. E.P.A., No. 3:15-CV-59, 2015 WL 5060744, at *1 (D.N.D. Aug. 27, 2015). But even as some states, industry, farmers and ranchers argue that the rule expands CWA jurisdiction, environmental groups maintain that the rule fails to extend categorical jurisdiction over many ecologically important wetlands, in particular prairie potholes in the Great Plains, which provide important habitat for waterfowl in the region. See Annie Snider, Obama Admin Finalizes WOTUS as Stakeholders Gird for Battle, GREENwIRE (May 27, 2015), http://www.eenews.net/ greenwire/2015/05/27/stories/1060019196.

221. See James City Cnty. v. EPA, 12 F.3d 1330, 1336 (4th Cir. 1993) (“Ultimately... recognizing the EPA's expertise and concentrated concern with environmental matters, Congress gave the final decision whether to permit a project to that agency.”).

222. See supra Parts II (NEPA), III (NHPA), and IV (ESA).

223. See EPA, EPA CleAn WATER ACt SECtion 404(C) FACt SheEt, http://water.epa.gov/ type/wetlands/outreach/upload/404c.pdf. In fact, almost all of these vetoes took place between 1980 and 1990. See generally Blumm \& Mering, supra note 199. 
more powerful than under the ESA because a section 404(c) veto is actually determinative, rather than "virtually" so.224 The nearly unconditional nature of EPA's veto power may explain why the agency uses it so rarely. Since section 404(c) authority gives EPA the last word on interpreting the section 404(b)(1) guidelines, it can affect the Corps' decisions indirectly, just as expert agencies do under the ESA and, to some extent, under both NEPA and the NHPA. This authority gives EPA considerable influence over the Corps' decisions to issue permits and the conditions the Corps includes in them-all without exercising a veto. 225

EPA's ability to veto permits retroactively, ratified in Mingo Logan,226 underscores the agency's authority to exert oversight over discharges even after the Corps has issued a section 404 permit. ${ }^{227}$ Coupled with EPA's significant leverage over actions it does not veto, the agency's veto power confers more substantive decision-making authority than any of the other expert agencies discussed above. Additionally, because EPA may make its veto decisions without considering economic factors 228 this dynamic allows for more environmentally sensitive decision making.

\section{CONDitions And Prescriptions Under the Federal Power ACT}

The FPA authorizes the Federal Energy Regulatory Commission (FERC) to issue nonfederal hydropower licenses on navigable waters. ${ }^{229}$ The FPA, originally an achievement of the Progressive Conservation Era,230 gives resource agencies such as federal land managers and fishery agencies the

224. Bennett v. Spear, 520 U.S. 154, 170, 177 (1997) (finding that under the ESA, although the decision as to whether an action results in "jeopardy" to a listed species rests in the hands of the action agency, a Service "jeopardy" finding is "virtually determinative" in judicial review of the action agency's decision).

225. See Kim Diana Connolly, STEPHEn M. JoHnson \& Douglas R. WiLliams, WetLands LaW AND Policy: UndeRsTANDING SECTION 404284 (2006); see also Blumm \& Mering, supra note 199.

226. See supra notes 204-209 and accompanying text.

227. For example, during the four years between the Corps' issuance of the permit to Mingo Logan Coal and EPA's veto, EPA sent a letter to the Corps requesting that it "suspend, revoke, or modify" Mingo Logan's permit based on "new information and circumstances ... which justify reconsideration of the permit." Mingo Logan Coal Co. v. EPA, 714 F.3d 608, 610-11 (D.C. Cir. 2013), cert. denied, 134 S. Ct. 1540 (2014) (quoting Letter from EPA Region III to U.S. Army Corps of Eng'rs, Huntington Dist. at 1 (Sept. 3, 2009)). The Corps responded that it would not do so, possibly because it did not think EPA had the power to veto permits after issuance. However, now that the D.C. Circuit has confirmed that EPA possesses retroactive veto authority, similar letters may convince the Corps to modify existing permits.

228. See supra notes 199-203 and accompanying text.

229. 16 U.S.C. § 797(e) (2012).

230. The 1920 FPA was a victory for Progressive Conservationists who wanted federal control of important hydroelectric resources over utilities and resource rich states that wanted to retain control. See, e.g., D. H. Cole, Reviving the Federal Power Act's Comprehensive Plan Requirement: A History of Neglect and Prospects for the Future, 16 ENVTL. L. 639, 653 (1986); see generally SAMUEL P. HAYS, Conservation And The Gospel Of Efficiency: The Progressive Conservation Movement 1890-1920 (1959). 
ability to issue conditions, prescriptions, and recommendations under three different provisions. ${ }^{231}$ This Part explains each of these issues, analyzing the effect of expert agency participation on FERC licensing.

\section{A. Federal Land Manager Conditioning Authority Under Section 4(e)}

Section 4(e) of the FPA authorizes federal land managers to issue conditions attached to nonfederal hydropower licenses in order to adequately protect the federal "reservation" 232 upon or within which a hydropower project is located.233 As the case law discussed below demonstrates, section 4(e) authority is broad enough to grant land managers real decision-making power. And, although this provision's authority is geographically limited to licensed projects on reservations, land managers have considerable discretion in their exercise of that power within that arena.

The seminal court interpretation of section 4(e) was the Supreme Court's 1984 decision in Escondido Mutual Water Co. v. La Jolla, Rincon, San Pasqual, Pauma, \& Pala Bands of Mission Indians, ${ }^{234}$ which clarified the effect of federal land manager conditions, as well as the geographical limits of that authority. In Escondido, several Indian tribes challenged FERC's reissuance of a license to continue operation of a dam and canal on and near several Indian reservations. ${ }^{235}$ The dam and canal diverted the San Luis Rey River to provide water to the San Diego County cities of Vista and Escondido, depriving the reservations of water. ${ }^{236}$ The federal land manager, the Bureau of Indian Affairs, proposed a series of conditions in order to protect the reservations' use of water, ${ }^{237}$ but FERC issued the license without most of the conditions, believing that the FPA did not require their inclusion. ${ }^{238}$ The tribes contested the license, arguing the plain language of the statute-that licenses "shall be subject to and contain such conditions as the [federal land manager]

231. See generally Michael C. Blumm \& Vickie A. Nadol, The Decline of the Hydropower Czar and the Rise of Agency Pluralism in Hydroelectric Licensing, 26 COLUM. J. ENVTL. L. 81 (2001).

232. The FPA defines "reservations" to include "national forests, tribal lands embraced within Indian reservations, military reservations, and other lands and interests in lands owned by the United States, and withdrawn, reserved, or withheld from private appropriation and disposal under the public land laws.” 16 U.S.C. § 796(2) (2012). The Department of Interior Office of the Solicitor has concluded that the definition includes BLM lands (because they have been reserved from disposal since the 1930s) even though BLM lands generally have no reserved water rights. See George CogGins ET AL., FEDERAL PUBLIC LANDS AND RESOURCES LAW 622 (7th ed. 2014) (citing a 2001 Solicitor's Opinion).

233. 16 U.S.C. § 797(e) (“[L]icenses shall be issued within any reservation only after a finding by the Commission that the license will not interfere or be inconsistent with the purpose for which such reservation was created or acquired, and shall be subject to and contain such conditions as the Secretary of the department under whose supervision such reservation falls shall deem necessary for the adequate protection and utilization of such reservation.”). This language was included in the original 1920 Federal Water Power Act, Pub. L. No. 66-280, 41 Stat. 1063 (1920).

234. 466 U.S. 765 (1984)

235. Id. at 769.

236. Id. at 767-68.

237. Id. at 770 .

238. Id. 
shall deem necessary for the adequate protection and utilization of such reservation"239_required FERC to accept, without modification, the federal land manager's conditions. ${ }^{240}$ The Supreme Court agreed with the tribes, ruling that "[t]he mandatory nature of the language chosen by Congress appears to require that [FERC] include the [land manager's] conditions in the license even if it disagrees with them." 241 Thus, the Court decided that FERC had to include the federal land managers' conditions in its licenses.

On the other hand, the Supreme Court interpreted the statutory language "within any reservation" to impose geographical limits on land managers' section 4(e) conditioning authority. Although three of the reservations at issue in Escondido contained physical elements of the hydropower project, the other three did not. ${ }^{242}$ The licensee argued that the statute authorized land manager conditions only for licenses "within" reservations. ${ }^{243}$ The Supreme Court agreed and, reversing the Ninth Circuit, decided that "within" meant that the project must be physically within the reservation boundaries. ${ }^{244}$

At least one court since Escondido has interpreted the decision to give federal land managers broad authority over hydroelectric licensing if any part of a project lies within a federal reservation. In City of Tacoma v. Federal Energy Regulatory Commission, the D.C. Circuit ruled that even a small part of a hydropower project, such as power lines or access roads, triggers section 4(e) conditioning authority. 245 In addition, the court upheld land manager conditions that were not even specifically related to the power line or access road but concerned the project as a whole, including any condition "reasonably related to protecting the reservation." 246 Thus, as long as some part of the project touches part of a reservation, federal land managers have the authority to impose mandatory license conditions on hydropower projects.

Also at issue in City of Tacoma was the timing of federal land managers' ability to impose conditions on the Cushman Project, a major hydroelectric project on the Skokomish River in Washington. ${ }^{247}$ Similar to the Mingo Logan

239. 16 U.S.C. § 797(e) (2012)

240. Escondido, 466 U.S. at 779.

241. Id. at 772

242. Id. at 788 .

243. Id. at 780; see 16 U.S.C. § 797(e) (“[L]icenses shall be issued within any reservation ... and shall be subject to and contain such conditions as the Secretary of the department under whose supervision such reservation falls shall deem necessary for the adequate protection and utilization of such reservation.") (emphasis added)).

244. Escondido, 466 U.S. at 784.

245. City of Tacoma v. Fed. Energy Regulatory Comm'n, 460 F.3d 53, 66 (D.C. Cir. 2006) (interpreting the Supreme Court's statement in Escondido that "[i]t is clear that Congress concluded that reservations were not entitled to the added protection provided by the proviso of $\S 4$ (e) unless some of the licensed works were actually within the reservation," to mean that "'some' means 'some'; it does not mean 'all,' or even 'a lot.”').

246. Id. at 67.

247. Id. at 59, 64; see 18 C.F.R. § 3.34(b) (2015) (“All comments (including mandatory ... terms and conditions or prescriptions) on an application for ... [a] license must be filed with the Commission no later than 60 days after issuance by the Commission of public notice.”). 
404(c) veto case, 248 FERC had attempted to put a time limit on land managers' conditioning authority, 249 arguing that because the agencies exceeded that time limit for the Cushman Project, it need not include the conditions. But the D.C. Circuit decided that the attempt to impose an administrative time limit exceeded FERC's statutory authority, stating that “[t]hough FERC makes the final decision as to whether to issue a license, FERC shares its authority to impose license conditions with other federal agencies." 250 In so ruling, the court recognized that licensing under the FPA established a shared decisionmaking paradigm among federal land managers and FERC. 251

Consequently, section 4(e) of the FPA, like section 404(c) of the CWA, explicitly recognizes shared decision-making power. Unlike NEPA, the NHPA, and the ESA, where the expert agency can only indirectly affect the action agency's decision through judicial review or the threat thereof, the FPA affirmatively delegates decision-making authority to land managers. The FPA seems similar to section 404(c), where EPA faces a binary choice to either veto or not veto a Corps permit. By contrast, FPA land managers can affect licensing decisions in many different ways, since any conditions they promulgate must appear in the FERC license. Put otherwise, these agencies can directly alter the construction of licensed projects. However, just as the jurisdictional prerequisite of "waters of the United States" limits EPA's CWA vetoes, the geographical boundaries of federal reservations confine land managers' section 4(e) conditioning authority.

\section{B. Federal Fishery Manager Conditioning Authority Under Section 18}

Section 18 of the FPA authorizes federal fishery managers to prescribe "fishways," usually fish ladders aiding upstream passage but also including downstream passage devices, at licensed projects. ${ }^{252}$ Although Congress

248. See supra notes 204-209 and accompanying text.

249. 18 C.F.R. $§ 4.34$ (b) ("All comments (including mandatory and recommended terms and conditions or prescriptions) on an application for exemption or license must be filed with the Commission no later than 60 days after issuance by the Commission of public notice declaring that the application is ready for environmental analysis.”).

250. City of Tacoma, 460 F.3d at 65.

251. However, the power to issue conditions is not unconfined. Land managers' conditions must be "reasonably related to [the goal of adequate protection and utilization of reservations], otherwise consistent with the FPA, and supported by substantial evidence.” Escondido Mutual Water Co. v. La Jolla, Rincon, San Pasqual, Pauma, \& Pala Bands of Mission Indians, 466 U.S. 765, 778 (1984). Judicial challenges must be filed in the federal courts of appeal. 16 U.S.C. § 825l(b) (2012).

252. Federal Power Act, 16 U.S.C. § 811 (2012) ("[FERC] shall require the construction, maintenance, and operation by a licensee at its own expense of ... such fishways as may be prescribed by the Secretary of the Interior or the Secretary of Commerce, as appropriate.”). After some controversy, see Blumm \& Nadol, supra note 231, at 109, in the Energy Policy Act of 1992 Congress defined a "fishway" as "limited to physical structures, facilities, or devices necessary to maintain all life stages of such fish, and project operations and measures related to such structures, facilities, or devices which are necessary to ensure the effectiveness of such structures, facilities, or devices for such fish.” Energy Policy Act of 1992, Pub. L. No. 102-486, § 1701(b), 106 Stat. 2776, 3008. 
established section 18 authority nearly a century ago in 1920,253 the provision was a sleeper until 1999, when, in American Rivers v. Federal Energy Regulatory Commission, the Ninth Circuit used Escondido's reasoning to decide that section 18 prescriptions, like section 4(e) conditions, are mandatory. 254

In American Rivers, environmentalists challenged FERC's decision to relicense several hydropower facilities on the McKenzie River in Oregon because the agency failed to include prescriptions submitted by fishery managers. ${ }^{255}$ FERC maintained that because it had fully explained its reasoning for rejecting the prescriptions, it had no duty to include them in the license. ${ }^{256}$ The Ninth Circuit, echoing Escondido, ruled that section 18 contains "a clear congressional delegation" of authority to federal fishery managers. 257

Moreover, the American Rivers court rejected FERC's attempt to "reclassify" mandatory section 18 prescriptions as nonmandatory recommendations. ${ }^{258}$ Specifically, FERC argued that the Services' prescriptions 259 issued under section 18 were not actually "fishway prescriptions," and therefore could be rejected as nonbinding section 10(j) recommendations. ${ }^{260}$ But the Ninth Circuit determined that FERC "may not modify, reject, or reclassify any prescriptions submitted by the [Services] under color of section 18. Where FERC disagrees with the scope of a fishway prescription, it may withhold a license altogether or voice its concerns in the court of appeals ...."261 Thus, section 18 prescriptions constitute another affirmative delegation of decision-making authority to expert agencies, one reviewable only by a court of appeal, not by FERC. 262

253. See Federal Water Power Act, Pub. L. No. 66-280, 41 Stat. 1063 (1920) (codified as amended at 16 U.S.C. § 811)

254. 201 F.3d 1186, 1211 (9th Cir. 1999).

255. Id. at 1192 .

256. Id. at 1206 .

257. Id. at 1207.

258. Id. at 1210; see infra notes263-264 and accompanying text.

259. The prescriptions FERC rejected, all of which involved structures rather than project operations, included "imposition of fish mortality standards at the fish screens of Leaburg and Walterville and at the Leaburg rollgates; construction of tailrace barriers; delays in raising the Leaburg Lake water level; delays in the construction of diversion structures at Walterville; salvage of fish prior to any new construction at Walterville's tailrace; annual inspection of the Walterville tailrace; agency control over final design and monitoring of fishways; and agency enforcement of the licensee's duty to maintain fishways in efficient operating condition “American Rivers, 201 F.3d at 1192 n.11.

260. Id. at 1192.

261. Id. at 1210. The FPA gives jurisdiction over judicial review of FERC licenses to "the United States Court of Appeals for any circuit wherein the licensee or public utility to which the [license] relates is located or has its principal place of business, or in the United States Court of Appeals for the District of Columbia ....” 16 U.S.C. § 825l(b) (2012).

262. See City of Tacoma v. Fed. Energy Regulatory Comm'n, 460 F.3d 53, 59,64 (D.C. Cir. 2006). Like section 4(e) land-manager conditions, fishery agency prescriptions must be consistent with the law and supported by substantial evidence. Wisconsin Power \& Light Co. v. Fed. Energy Regulatory Comm’n, 363 F.3d 453, 461 (D.C. Cir. 2004). 


\section{Recommendations to Protect Fish and Wildlife Under Section 10(j)}

Section 10(j) of the FPA authorizes the federal Services and their state counterparts (collectively "fishery agencies") to make recommendations to FERC to "protect, mitigate damages to, and enhance fish and wildlife" affected by licensed hydropower projects. ${ }^{263}$ Unlike section 18 or section 4(e), section 10(j) governs recommendations involving project operations rather than physical structures. Under it, if FERC does not include the fishery agencies' recommendations as conditions of the relicensing, FERC must publish findings that the recommendations would be inconsistent with the FPA's purposes and that the conditions FERC has included would adequately protect, mitigate, and enhance fish and wildlife. ${ }^{264}$ In American Rivers, the Ninth Circuit recognized that "[s]ection 10(j) and section 4(e), the provision at issue in Escondido, set forth very different roles for [FERC] to play in the hydropower relicensing process," concluding that section 10(j) does not confer final conditioning authority on resource agencies. ${ }^{265}$ Section $10(\mathrm{j})$ is therefore more like NEPA, the NHPA, and the ESA, which reserve final decision-making authority for the action agency.

For example, in Idaho Rivers United v. Federal Energy Regulatory Commission, fishery agencies recommended that five licensed hydroelectric dams on the Snake River not create reservoirs for future power generation, but instead let the river run free. ${ }^{266}$ Fishery agencies issued these recommendations under section 10(j), not section 18, because they involved project operations rather than physical structures. When FERC declined to include these recommendations in its license conditions, environmentalists sued. The Ninth Circuit upheld FERC's decision not to include fishery agencies' section 10(j) recommendations because FERC had adequately explained its reasoning for not including them, 267 illustrating that even though fishery agency recommendations play an important role in judicial review, section 10(j) leaves final decision-making authority with the action agency, in sharp contrast to both sections 18 and 4(e). ${ }^{268}$

\footnotetext{
263. 16 U.S.C. § 803(j) (2012).

264. Id.

265. American Rivers, 201 F.3d at 1203-04.

266. 189 F. App’x 629, 631 (9th Cir. 2006).

267. Id. at 633. The court determined that FERC's failure to incorporate specific measures to protect sturgeon pending the licensee's submission of a sturgeon conservation plan (due within one year of license issuance) was not unreasonable, noting that sturgeon were not listed under the ESA, and that the license would maintain current levels of fish protection and water quality and proceed with habitat improvements. Id at 635-36.

268. CWA section 401 likewise gives final decision-making authority to states concerning conditions necessary to maintain state water quality standards for federal permits that may result in discharges to navigable waters (e.g. hydropower projects). 33 U.S.C. § 1341 (2012). States must certify these projects before FERC may license them, and the Supreme Court has recognized that such certifications can include conditions related to minimum stream flow requirements necessary to protect a fishery. PUD No. 1 of Jefferson Cnty. v. Wash. Dep’t of Ecology, 511 U.S. 700, 712 (1994). FERC is
} 
Nevertheless, as in the case of expert agency consultation or comment under NEPA, the NHPA, or the ESA, American Rivers recognized that FERC must afford "significant deference" to fishery agencies' recommendations under section 10(j). ${ }^{269}$ In fact, the statute contemplates that FERC "shall attempt to resolve any... inconsistency [between fishery agencies' recommendations and FPA purposes and requirements], giving due weight to the recommendations, expertise, and statutory responsibilities of such agencies."270 Thus, for FERC to reject a fishery agency's recommendations, it must adequately explain, with the requisite deference to the expert agency, its reasons for doing so.

\section{The Effect of the Energy Policy Act of 2005 on Conditioning Authority}

In 2005 Congress significantly amended the FPA with the Energy Policy Act (EPAct), which added procedures that have affected the process by which resource agencies 271 exercise their FERC license-conditioning authority. ${ }^{272}$ The EPAct ${ }^{273}$ left the decision-making structure of the FPA intact, but amended sections $4(\mathrm{e})$ and 18 to permit parties to relicensing proceedings to request "trial-type hearings" and allow licensees to propose alternative conditions and prescriptions. ${ }^{274}$

The EPAct allows any party to relicensing proceedings to request an up to ninety day trial-type hearing before an administrative law judge (ALJ) in order to resolve disputed issues of material fact related to conditions or prescriptions. ${ }^{275}$ The apparent goal of the amendments was to require the development of a more complete administrative record, particularly documentation of the reasons supporting the mandatory conditions of expert

obligated to include such conditions, regardless of whether it thinks they are reasonably related to water quality. American Rivers, Inc. v. Fed. Energy Regulatory Comm’n, 129 F.3d 99, 106 (2d Cir. 1997).

269. Id. at 1205 (emphasis in original) (quoting Kelley ex rel. Mich. Dep’t of Nat. Res. v. Fed. Energy Regulatory Comm’n, 96 F.3d 1482, 1486 (D.C. Cir. 1996)).

270. 16 U.S.C. § 803(j)(2).

271. Resource agencies include federal land managers under section 4(e) and fishery agencies under sections 18 and $10(\mathrm{j})$.

272. 16 U.S.C. §§ 797(e), 811 (2012).

273. Energy Policy Act of 2005, Pub. L. No. 109-58, 119 Stat. 594 (2005).

274. 16 U.S.C. §§ 797(e), 811, 823d (2012).

275. Id. $\S \S 797(\mathrm{e}), 811$. The amendments directed the resource agencies to promulgate rules establishing procedures for these trial-type hearings, which the Departments of Agriculture, Commerce, and Interior did the same year. Resource Agency Procedures for Conditions and Prescriptions in Hydropower Licenses, 70 Fed. Reg. 69,804 (Nov. 17, 2005). The regulations require the resource agency to first file its proposed conditions or prescriptions with FERC, along with the supporting rationale. 7 C.F.R. $\S 1.620$ (2015). Within thirty days of the initial filing, any party to the relicensing can request a hearing before an ALJ. Id. $\S 1.621$. To do so, the party must identify a disputed issue of material fact and provide a list of witnesses and exhibits. Id. The resource agency has fifty-five days from the initial filing deadline (of the proposed conditions) to respond, provide its own list of witnesses and exhibits, consolidate hearings with substantially similar disputes, and refer the case to the ALJ. Id. $\S \S 1.624-1.626$. The discovery period, hearing, and final decision all must take place within 120 days of the referral notice. Id. § 1.660 . 
fishery agencies. However, a 2010 Government Accountability Office (GAO) report determined that in the five years following the EPAct's passage, only three hearings out of a total of 103 eligible projects - less than three percentproduced an ALJ decision. ${ }^{276}$ Licensees requested hearings for only eighteen projects, most of which resulted in a settlement agreement. ${ }^{277}$ Of the issues decided in the three hearings that resulted in an ALJ decision, the majority of the findings favored the resource agency, not the licensee. ${ }^{278}$

Despite ALJs' tendency to rule in a resource agency's favor, the statutory authorization of hearings may have the effect of producing more favorable conditions for licensees. This is likely because trial-type hearings are expensive and time consuming; agencies estimate that the three hearings between 2005 and 2010 cost $\$ 3.1$ million. ${ }^{279}$ In GAO interviews with various stakeholders about the new trial-type hearings, the licensees explained that resource agencies were more willing to negotiate potential conditions and prescriptions to avoid requests for trial-type hearings. ${ }^{280}$ Many resource agency officials thought that the threat of expensive trial-type hearings pressured them to issue agreeable conditions and produced less favorable conditions. ${ }^{281}$ Thus, even though licensees infrequently requested hearings, the threat of them may significantly affect resource agency's decisions concerning appropriate FPA conditions and prescriptions.

The EPAct also added section 33 to the FPA, which enables licensees to propose alternative conditions to the resource agencies. ${ }^{282}$ The GAO found that licensees proposed alternative conditions in only twenty-four percent of relicensing proceedings between 2005 and 2010 - all of which were

276. U.S. Gov't Accountability Office, GAO-10-770, Hydropower Relicensing: Stakeholders Views on the Energy Policy Act Varied, But More Consistent Information Needed (2010), http://www.gao.gov/products/GAO-10-770.

277. Id. at 13 .

278. In those three hearings, the parties raised thirty-seven separate issues of material fact to the ALJs. ALJs ruled for the agency on twenty-give of those issues, for the licensee on six, and split decisions for the remaining six. Id. at 13. Despite the number of issues decided against the licensee, apparently no licensees challenged any of the findings in these administrative trial-type hearings in court.

279. Id. at 16 .

280. Id. at 14 .

281. Id. at 16 .

282. 16 U.S.C. $\S 823 d$ (a) (2012). Section 33 allows licensees to offer alternative prescriptions to those offered under section 18. Id. § 823d(b). The procedures are the same for alternative section 18 prescriptions as they are for section 4 (e) conditions. Section 33 requires the secretary of the relevant resource agency to determine if the licensee's proposed alternative condition is either less costly or results in more electrical productivity than the Secretary's condition. Id. $\S 823 \mathrm{~d}(\mathrm{a})(2),(\mathrm{b})(2)$. The agency then may submit either its original condition or the proposed alternative to FERC, along with an explanation of the basis for its decision. Id. $\S 823 \mathrm{~d}(\mathrm{a})(4)$, (b)(4). FERC may refer the dispute to its Dispute Resolution Service instead of automatically accepting the conditions, if it determines that the conditions would be inconsistent with the purposes of the FPA. Id. § 823d(a)(5), (b)(5). Nevertheless, the opinion of the Dispute Resolution Service is only advisory, and the resource agency may chose not to accept FERC's recommendations. Id. § 823d(a)(5), (b)(5). 
rejected.283 Yet the GAO also found that agencies modified many of their original conditions in settlement negotiations with the licensees. ${ }^{284}$ Although the resource agencies explained why they rejected the proposed alternatives, they did not say why the settlement negotiations resulted in modified final conditions. ${ }^{285}$ The answer may have been a desire to avoid the time and expense of writing a formal written statement upon rejection of a licensee's proposed condition. In other words, resource agencies may have traded more favorable conditions for the licensee's agreement to withdraw proposed alternatives. ${ }^{286}$ It seems that the proponents of EPAct achieved their objectives of reducing the economic effects of resource agency conditioning authority by given licensees the leverage to negotiate better terms.

Although the EPAct left the FPA's structure for mandatory conditions intact, the amendments threaten to produce fewer protective hydroelectric license conditions. ${ }^{287}$ The threat of trial-type hearings and the potential drain of resources may be pressuring agency officials into settling with licensees to modify conditions. And, as the 2010 GAO report concluded, the ensuing settlements lack transparency because agencies do not explain how and why the proposed alternatives are as effective as those originally proposed. ${ }^{288}$ However, despite the fact that the new procedures appeared to at least indirectly favor the licensees, the licensees invoked the additional procedure in only twenty-five of the 103 relicensing proceedings between 2005 and 2010-less than one-quarter of the total. ${ }^{289}$ Moreover, at least as of 2010, the use of the procedures appears to be declining. 290

\section{SHARED SOVEREIGNTY AND ENVIRONMENTAL DECISION MAKING}

The shared sovereignty policy reflected in the statutes analyzed in this Article tends to produce more environmentally protective decision making. Under NEPA, comments from expert agencies-usually urging closer consideration of the environmental effects of their proposed actions-not only influence judicial review but also action agency proposals and frequently result in altered projects. ${ }^{291}$ Similarly, NHPA consultation with states, tribes, and the Council often results in more properties being identified as historic ${ }^{292}$ and

283. U.S. Gov’T ACCOUNTABILITY OfFICE, supra note 276, at 7.

284. Id. at 12. It does not appear that any of the proposed alternatives resulted in a referral to FERC's Dispute Resolution Service.

285. Id.

286. Id. at 20 .

287. Id. at 15 .

288. Id. at 12

289. Id. at 2.

290. Id. at 9 .

291. See supra notes $64-67$ and accompanying text.

292. See supra Part II.B. 
encourages action agencies to ensure that their actions have no adverse effects on such properties. ${ }^{293}$

The shared sovereignty principle reflected in the ESA has produced decisions that protect listed species because the Services can and do use their concurrence authority to leverage environmentally protective changes to projects during informal consultation, ${ }^{294}$ or to effectively prohibit projects that jeopardize listed species or destroy critical habitat. 295 Under the CWA, EPA's veto power has led to environmentally protective decisions because of the leverage it confers and because, unlike the Corps, EPA can make decisions based solely on environmental concerns without considering economic factors. ${ }^{296}$ Finally, under the FPA's brand of shared sovereignty, resource managers can require nonfederal hydropower licenses to include conditions or prescriptions that protect fish and federal lands. 297

Since shared sovereignty decision making often produces more environmentally protective results and absorbs more time and administrative resources, it is perhaps unsurprising that these provisions can prove contentious. For example, agencies often attempt to avoid NEPA requirements by categorically excluding whole types of projects from NEPA procedure. 298 More concerning, shared sovereignty decision making often comes under fire from members of Congress and administrations. The Bush administration's attempt to promulgate counterpart ESA regulations was an effort to undermine the shared decision making established by section 7's consultation procedures. ${ }^{299}$ And while these attempts to undermine the shared sovereignty paradigm proved unsuccessful, they may portend future efforts to avoid sharing decision-making power-the existing ESA regulations still authorize future counterpart regulations. 300

Perhaps fearful of the kind of direct decision-making power expert agencies wield under the CWA and the FPA, Congress has also made efforts to confine that power. Under the CWA, Congress is currently considering a bill that would temporally limit EPA's ability to veto Corps permits, so that EPA could not veto permits until after the Corps issues a final permit. ${ }^{301}$ Moreover, Congress has already succeeded in somewhat undermining the shared decision making under the FPA by passing the EPAct, which subjects expert resource managers' prescriptions and conditions to trial-type hearings. ${ }^{302}$ Although the

293. See supra notes $130-147$ and accompanying text.

294. See supra note 168 and accompanying text.

295. See supra notes 191-193 and accompanying text.

296. See supra notes 199-203 and accompanying text.

297. See supra notes 232-262 and accompanying text.

298. See supra note 12.

299. See supra notes $170-180$ and accompanying text.

300. See supra note 170 and accompanying text.

301. See supra note 216 and accompanying text.

302. See supra notes 271-275 and accompanying text. 
EPAct procedures are not often invoked, they can and have led to less environmentally protective conditions. 303

On the other hand, Congress and the agencies have also acted to preserve or expand shared sovereignty dynamics under several of these statutes. For example, under the NHPA, Congress in 1992 recognized the expertise of tribes in identifying historic properties, adding them as required consulting parties under the NHPA. ${ }^{304}$ And one explanation for the relative dearth of CWA vetoes over the last two decades is that the Corps has learned from experience that it must defer to EPA, at least on the most controversial fill proposals. 305 Shared sovereignty may be an acquired characteristic of administrative law.

\section{CONCLUSION}

The principle of shared sovereignty is deeply embedded in environmental law. Save for the FPA in the Progressive Conservation Era, Congress enacted all of the statutes examined in this Article between 1966 and 1973.306 Over the ensuing decades they have become firmly established presences within the American legal system — as the litigation surveyed above makes clear.

Shared sovereignty also influences the regulatory system through less direct means. The shared sovereignty paradigm helps to explain what otherwise might seem to be haphazard results from NEPA litigation, since courts have shown they are influenced by the comments of agencies with environmental expertise. 307 It is also at work in the involvement of states, tribes, the Council, and the Keeper in NHPA consultation, although that statute's structure promotes preservation of historic properties with less reliance on litigation than NEPA. ${ }^{308}$ Shared sovereignty similarly characterizes the federal consultation processes established by the ESA, in which the Services have a virtually determinative role in assessing action agencies' statutory compliance. ${ }^{309}$ In the case of CWA vetoes under section 404(c) and resource manager conditions and

303. See supra note 287 and accompanying text.

304. See supra notes 87-89 and accompanying text.

305. See supra notes 227-228 and accompanying text; see also Blumm \& Mering, supra note 199.

306. Congress enacted the NHPA in 1966, National Historic Preservation Act of 1966, Pub. L. No. 89-665, 80 Stat. 915 (codified at 16 U.S.C. §§ 470-470x-6) (repealed and recodified at 54 U.S.C. §§ 300101-307108); NEPA in 1970, National Environmental Policy Act of 1969, Pub. L. No. 91-190, 83 Stat. 852 (1970) (codified at 42 U.S.C. §§ 4321-4370h); Section 404(c) of the CWA in 1972, Federal Water Pollution Control Act, Pub. L. No. 92-500, 86 Stat. 816 (1972) (codified at 33 U.S.C. §§ 12511388 et. seq.); and Section 7 of the ESA in 1973, Endangered Species Act of 1973, Pub. L. 93-205, 87 Stat. 884 (1973) (codified at 16 U.S.C. §§ 1531-1544). By contrast, sections 4(e) and 18 of the FPA were enacted in 1920, Federal Water Power Act, c. 285, § 4, 41 Stat. 1065 (1920) (codified at 16 U.S.C. $\S \S 791-828 \mathrm{c})$, with section 10(j) added in the Electric Consumers Protection Act of 1986, Pub.L. No. 99-495, 100 Stat. 1243 (1986) (codified at 16 U.S.C. § 803(j)).

307. See supra Part II.

308. See supra Part III.

309. See supra Part IV. 
prescriptions under the FPA, the expert agencies have an even greater role in permit and license decisions. ${ }^{310}$

Although the type of sovereignty shared in our study varied quite a bitfrom apparently advisory to virtually determinative to actually determinativethe notion that a pluralism of federal opinion improved decision making was a consistent theme. In the twenty-first century, continuing the shared sovereignty principle that was laid down over four decades ago seems wise, given the complex scientific, economic, and ecological issues at the root of modern environmental law.

310. See supra Part V (section 404(c) permit vetoes), Part VI (FPA licensing).

We welcome responses to this Article. If you are interested in submitting a response for our online companion journal, Ecology Law Currents, please contact cse.elq@law.berkeley.edu. Responses to articles may be viewed at our website, http://www.ecologylawquarterly.org. 